\title{
Tall-statured grasses: a useful functional group for invasion science
}

\author{
Susan Canavan (D) Laura A. Meyerson (D) Jasmin G. Packer $\mathbb{D} \cdot$ \\ Petr Pyšek (D) - Noëlie Maurel (i) - Vanessa Lozano (i) David M. Richardson (D) • \\ Giuseppe Brundu $(\mathbb{D} \cdot$ Kim Canavan $(\mathbb{D} \cdot$ Angela Cicatelli $(\mathbb{D} \cdot$ - Jan Čuda $(\mathbb{D} \cdot$ \\ Wayne Dawson $(\mathbb{D} \cdot$ Franz Essl $\mathbb{D}$ - Francesco Guarino $(\mathbb{D})$ Wen-Yong Guo $\mathbb{D}$ • \\ Mark van Kleunen $(\mathbb{D} \cdot$ Holger Kreft (iD) Carla Lambertini $(\mathbb{D} \cdot$ Jan Pergl • \\ Hana Skálová (D) - Robert J. Soreng • Vernon Visser (i) - Maria S. Vorontsova (D) \\ Patrick Weigelt $(\mathbb{D} \cdot$ Marten Winter $(\mathbb{D} \cdot$ John R. U. Wilson $(\mathbb{D})$
}

\begin{abstract}
Species in the grass family (Poaceae) have caused some of the most damaging invasions in natural ecosystems, but plants in this family are also among the most widely used by humans. Therefore, it is important to be able to predict their likelihood of naturalisation and impact. We explore whether plant height is of particular importance in determining naturalisation success and impact in Poaceae by comparing naturalisation of tall-
\end{abstract}

S. Canavan ( $ه)$ D D. M. Richardson · J. R. U. Wilson Centre for Invasion Biology, Department of Botany and Zoology, Stellenbosch University, Matieland 7602, South Africa

e-mail: sucanavan@gmail.com

\section{S. Canavan · J. R. U. Wilson}

South African National Biodiversity Institute,

Kirstenbosch Research Centre,

Private Bag X7, Claremont 7735, South Africa

\section{A. Meyerson}

Department of Natural Resources Science, The University of Rhode Island, Kingston, RI 02881, USA

\section{J. G. Packer}

Environment Institute, The University of Adelaide, Adelaide, SA 5005, Australia statured grasses (TSGs; defined as grass species that maintain a self-supporting height of $2 \mathrm{~m}$ or greater) to non-TSGs using the Global Naturalised Alien Flora database. We review the competitive traits of TSGs and collate risk assessments conducted on TSGs. Of the c. 11,000 grass species globally, 929 qualify (c. 8.6\%) as TSGs. $80.6 \%$ of TSGs are woody bamboos, with the remaining species scattered among 21 tribes in seven subfamilies. When all grass species were analysed, TSGs and non-TSGs did not differ significantly in the probability of naturalisation. However, when we analysed woody bamboos separately from the other grasses,

P. Pyšek · J. Čuda · W.-Y. Guo · J. Pergl · H. Skálová Department of Invasion Ecology, Institute of Botany, The Czech Academy of Sciences, 25243 Průhonice, Czech Republic

P. Pyšek · J. ̌̌uda

Department of Ecology, Faculty of Science, Charles University, Viničná 7, 12844 Prague, Czech Republic

N. Maurel · M. van Kleunen

Ecology, Department of Biology, University of Konstanz, Universitätsstrasse 10, 78467 Constance, Germany

V. Lozano · G. Brundu

Department of Agriculture, University of Sassari, Viale Italia 39, 07100 Sassari, Italy 
the percentage of TSGs that have naturalised was 2-4 times greater than that of non-TSGs for both bamboos and non-bamboo groups. Our analyses suggest that woody bamboos should be analysed separately from other TSGs when considering naturalisation; within the $\geq 2 \mathrm{~m}$ height class they do not naturalise at the same rate as other TSGs. Rapid growth rate and the capacity to accumulate biomass (a function of height) give many TSGs a competitive advantage and allow them to form monospecific stands, accumulate dense and deep litter mats, reduce light availability at ground level, and alter fire and nutrient-cycling regimes, thereby driving rapid ecosystem transformation. While the height distribution in grasses is continuous (i.e. no obvious break is evident in heights), the $2 \mathrm{~m}$ designation for TSGs defines an important functional group in grasses that can improve predictive modelling for management and biosecurity.

Keywords Arundo $\cdot$ Bamboos $\cdot$ Biological invasions · Height · Invasive species - Miscanthus .

Phragmites · Plant functional groups · Poaceae · Risk assessment

\section{Introduction}

A useful approach in studying alien plant invasions has been to identify broad patterns and correlates of

K. Canavan

Department of Zoology and Entomology, Rhodes

University, PO Box 94, Grahamstown, South Africa

A. Cicatelli · F. Guarino

Department of Chemistry and Biology “A. Zambelli”, University of Salerno, 84084 Fisciano, SA, Italy

\section{W. Dawson}

Department of Biosciences, Durham University, South Road, Durham DH1 3LE, UK

\section{F. Essl}

Division of Conservation, Vegetation and Landscape Ecology, University of Vienna, Rennweg 14, 1030 Vienna, Austria

M. van Kleunen

Zhejiang Provincial Key Laboratory of Plant Evolutionary Ecology and Conservation, Taizhou University, Taizhou 318000, China invasiveness and impacts, such as functional groups, and to use these to provide generalisations for management (Vilà and Pujadas 2001; Colautti et al. 2006; Pyšek and Richardson 2008; Novoa et al. 2015). Functional groups are sets of organisms that share attributes that confer similar morphological, physical, behavioural, biochemical or environmental responses to ecosystem processes (Lavorel et al. 1997; Pérez-Harguindeguy et al. 2016; Garnier et al. 2017). Functional groups can be used to identify species that respond similarly to environmental pressures and are therefore useful for predicting and managing impacts of alien species (Lavorel et al. 1997; Díaz and Cabido 1997).

Plant height is considered a key trait for ecological strategies (Grime et al. 1988; Westoby et al. 2002; Garnier and Navas 2012), and according to Tilman's (1982) resource competition theory, resource exploitation is proportional to individual biomass, with larger individuals exploiting a disproportionate amount of resources (DeMalach et al. 2016). Many studies have recognised the benefits of increased height for initial colonisation by alien plants, as it is associated with better light capture and competitive ability (Pyšek et al. 2012; Moodley et al. 2013; Gallagher et al. 2015). Among plants, invasions by tall-statured grasses (hereafter TSGs; Fig. 1) are particularly noted for their ability to dominate plant communities and alter ecosystem

H. Kreft · P. Weigelt

Biodiversity, Macroecology and Biogeography, University of Göttingen, 37077 Göttingen, Germany

H. Kreft

Centre of Biodiversity and Sustainable Land Use (CBL), University of Göttingen, 37077 Göttingen, Germany

\section{Lambertini}

Department of Bioscience, Aarhus University, Ole Worms Allé 1, 8000 Aarhus C, Denmark

R. J. Soreng

Department of Botany, National Museum of Natural History, Smithsonian Institution, Washington, DC, USA

V. Visser

Department of Statistical Sciences, Statistics in Ecology, Environment and Conservation, University of Cape Town, Rondebosch 7701, South Africa 
functioning (Meyerson et al. 1999; Lambert et al. 2010; Saltonstall et al. 2010). Recent studies have reviewed sub-groups of tall grasses such as invasive grasses that dominate aquatic ecosystems, and have argued that they are functionally similar and have generalizable impacts related to their competitive nature [e.g. Lambert et al. (2010) refer to "large-statured invasive grasses"].

More broadly, tall-statured grasses are potentially an important functional group in invasion science because (1) established populations of TSGs can cause significant negative ecological impacts (Pagad 2016; Canavan et al. 2017b); (2) large height and biomass contribute to specific environmental impacts, e.g. reduction in light availability, changes to fire regimes, and alteration of nutrient cycles (D'Antonio and Vitousek 1992; Meyerson et al. 1999; Brooks et al. 2004; Smith et al. 2013; Gaertner et al. 2014; Visser et al. 2016); (3) TSGs occur in grasslands, riparian areas and estuaries, as well as tropical and temperate forests, yet the abiotic and biotic impacts are often similar across ecosystems; (4) TSGs are increasingly cultivated for commercial purposes such as bioenergy production and phytoremediation and therefore present new risks (Mislevy and Fluck 1992; Czakó et al. 2005; Heaton et al. 2008; Jakob and Zhou 2009; Mirza et al. 2010; Chen et al. 2015); and (5) TSGs are often dominant components of the vegetation in their native ranges, providing biotic resistance to invasion (including against alien TSGs) (Sheley and James 2010). However, TSGs have not been fully explored as a distinct functional group until now.

Here, we review the usefulness of the TSG functional group for invasion science. We produce a preliminary list of TSGs, and test whether there is a

\section{Visser \\ African Climate and Development Initiative, University of Cape Town, Cape Town, Rondebosch 7701, South Africa}

M. S. Vorontsova

Comparative Plant and Fungal Biology, Royal Botanic Gardens, Kew, Richmond, Surrey TW9 3AE, UK

M. Winter

German Centre for Integrative Biodiversity Research

(iDiv) Halle-Jena-Leipzig, Deutscher Platz 5e, 04103 Leipzig, Germany

M. Winter

Leipzig University, Deutscher Platz 5e, 04109 Leipzig, Germany quantitative pattern in the naturalisation of grasses comparing TSGs with non-TSG grasses, for all grasses, only woody bamboo grasses, and all grasses other than woody bamboos. We identify which TSGs have been subject to risk assessments. We also discuss the invasion-science literature associated with TSGs, focussing on how competitive traits associated with increased height can affect the colonisation, invasion, and environmental impacts of alien grasses.

\section{Methods}

Defining and creating a list of tall-statured grasses

Height in grasses (defined here as average inflorescence height, as per Kew's GrassBase; http://www.kew.org/ data/grasses-db.html) varies across three orders of magnitude (2 cm-20 m; see Fig. 2). Efforts to classify vegetation into different height categories include Küchler (1949) and Dansereau (1951) who proposed that "tall herbaceous plants", including grasses, should have an average minimum height of $2 \mathrm{~m}$; Edwards (1983) proposed four height categories for grasses, with tall grasses being $1 \mathrm{~m}$ and greater than $2 \mathrm{~m}$ to be the largest height category; Lambert et al. (2010) considered "large-statured invasive grasses" to be greater than $1.5 \mathrm{~m}$ in height. There are clearly important correlates between height and ecological processes, such as competition for light, e.g. light reduction to the soil surface decreases dramatically from $2 \mathrm{~m}$ down (Meyerson et al. 1999). However, previously proposed height classifications lack a clear ecological justification for their categories, and instead have been developed for practical purposes such as for vegetation inventories, descriptions and surveys (Edwards 1983). We propose $2 \mathrm{~m}$ as an ecologically relevant height threshold amongst grasses, and define TSGs as species that are $\geq 2 \mathrm{~m}$. Grasses that maintain a height of $\geq 2 \mathrm{~m}$ experience a trade-off between other functional traits. Typical features associated with taller grasses include lignified culms, high growth rates, and abundant biomass (Table 1). For these reasons, and the common prior use of $2 \mathrm{~m}$ as the cut-off, we generated a preliminary list of "tall-statured grasses".

We extracted data on inflorescence height for all grass species from Kew's GrassBase. Our list of species was cleaned, updated and corrected; nonbamboo grasses were checked for synonyms using 
Kew's World Checklist of Selected Plant Families (http://apps.kew.org/wcsp/qsearch.do) and bamboo species were checked using the International Network for Bamboo and Rattan's (INBAR) global checklist (Vorontsova et al. 2016). Species that do not maintain their height independently (i.e. those listed as 'climbing', 'scandent-', 'rambling', 'prostrate', 'liana' and or 'leaning' [on other vegetation]) were removed from the list of TSGs, and were considered non-TSGs along with shorter species.

Incidence and extent of naturalisation

If increased height is advantageous for colonisation, we expected that TSGs would have higher rates of naturalisation compared to shorter grasses (i.e. nonTSGs). To test for this, we calculated whether: (1) TSGs are more likely to be naturalised in at least one region of the world (what we refer to as 'incidence of naturalisation'); and (2) for naturalised species, TSGs are more globally widespread outside their native range (which we refer to as 'extent of naturalization'; see e.g. Razanajatovo et al. (2016)). Data from the Global Naturalised Alien Flora (GloNAF) database were used for both analyses. The database covers 843 non-overlapping regions (countries, federal states, islands) covering around $83 \%$ of the Earth's land surface.

The effect of stature on the probability of a grass species becoming naturalised could simply mean that

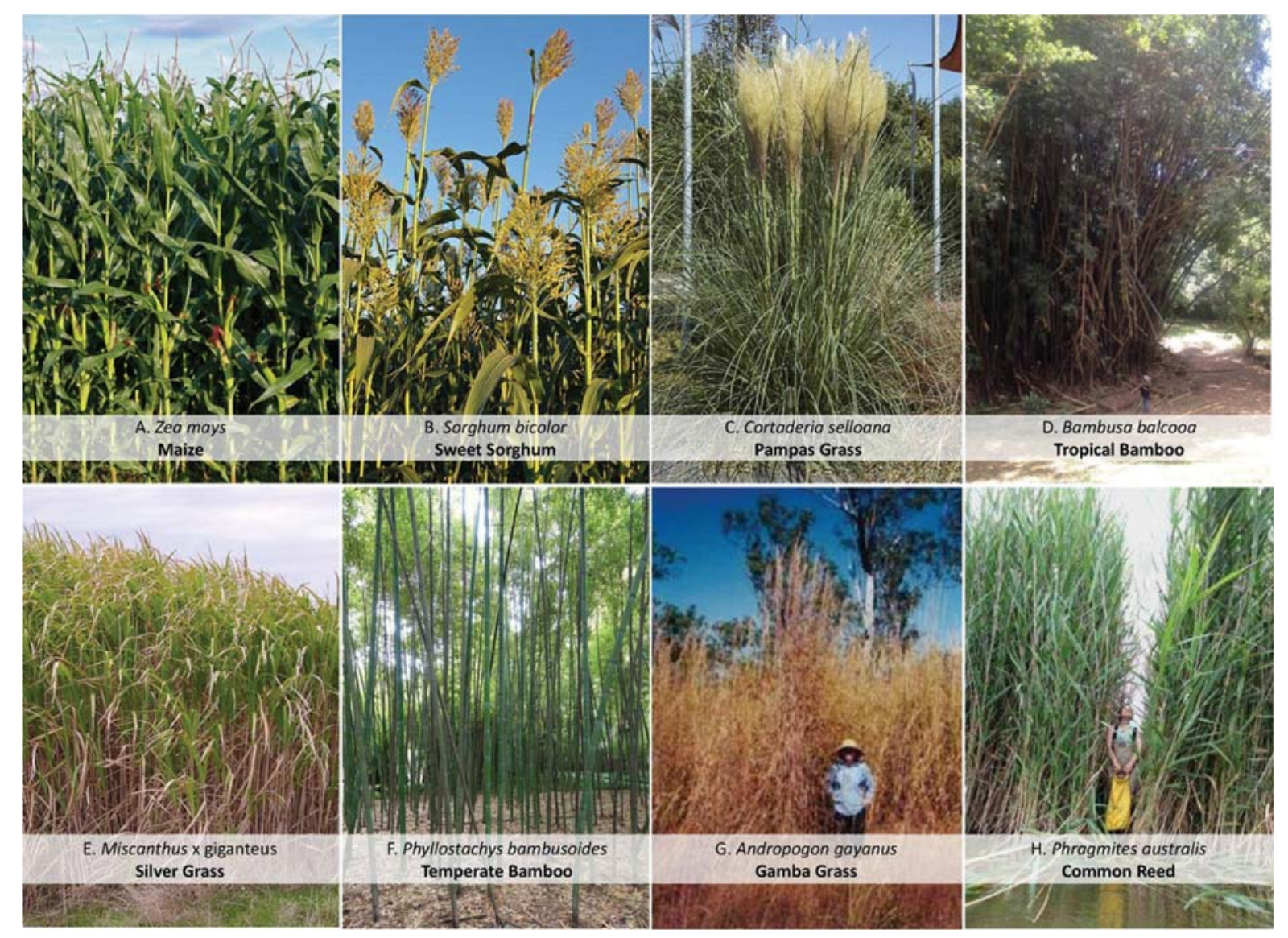

Fig. 1 Tall-statured grasses (TSGs) come in a variety of forms and occur in a range of different ecosystems (e.g. temperate forests, dry grasslands to tropical wetlands). They are useful to humans for food (a and $\mathbf{b}$ ), ornamental horticulture (c and $\mathbf{d}$ ), for biofuels (e and $\mathbf{f}$ ) and other uses ( $\mathbf{g}$ and $\mathbf{h}$ ). Several TSGs are associated with environmental impacts in invaded ranges due to their ability to form monospecific communities that exclude other vegetation types (d, $\mathbf{f}, \mathbf{g}$ and $\mathbf{h})$. Photographs: Wikimedia Commons (A: Christian Fischer (CC BY-SA 3.0 \& CC0); B: Wouter Hagens (CC BY-SA 3.0); E: Bgabrielle (CC-BY-SA3.0); F: Daderot ( $\mathrm{CC} 0)$ ) and other sources (C: Kijktuinen Nunspeet -http://www.kijktuinen.nl); D: Susan Canavan; G: retrieved from Rossiter-Rachor et al. 2009; H: Michigan Technological University) 


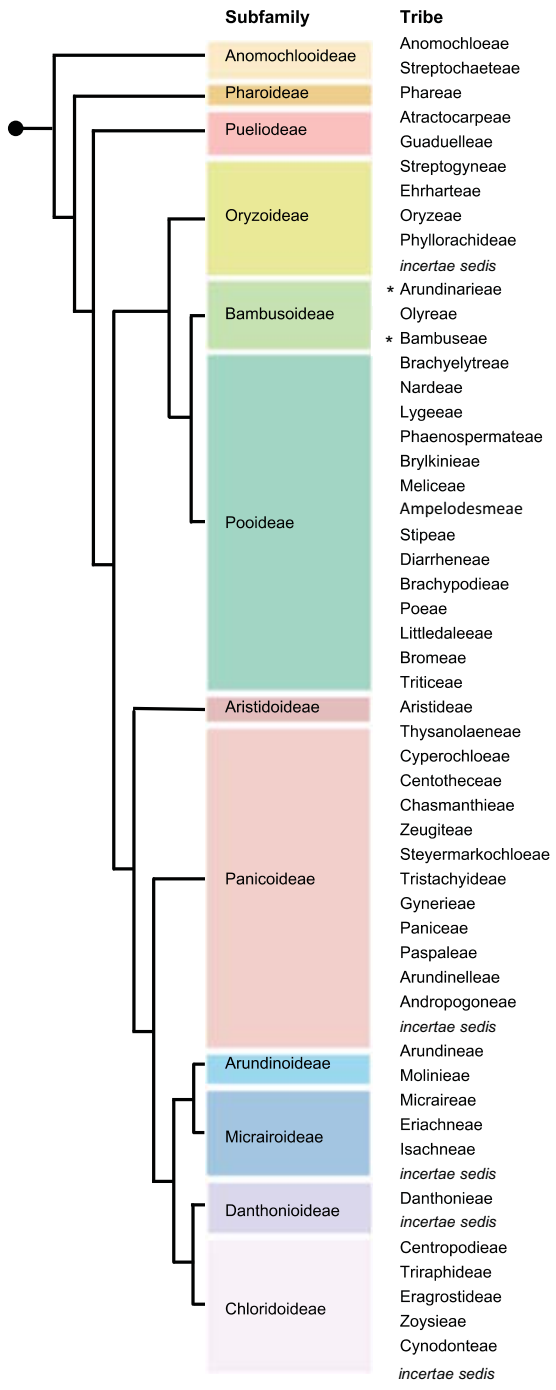

Fig. 2 Height distribution of grass species in subfamilies and tribes as per Soreng (2015)'s classification of Poaceae. Species within the black-outlined box have average bloom (inflorescence) heights of $\geq 2 \mathrm{~m}$. Note that not all of these taxa are defined in this paper as tall-statured grasses (TSGs) as some taxa do not maintain their height independently (e.g. climbing species). The area of the black circles is proportional to the

TSGs are more likely to be traded because of their ornamental value. To test for this, we used data on the plant trade sourced from Dave's Garden Plant Files
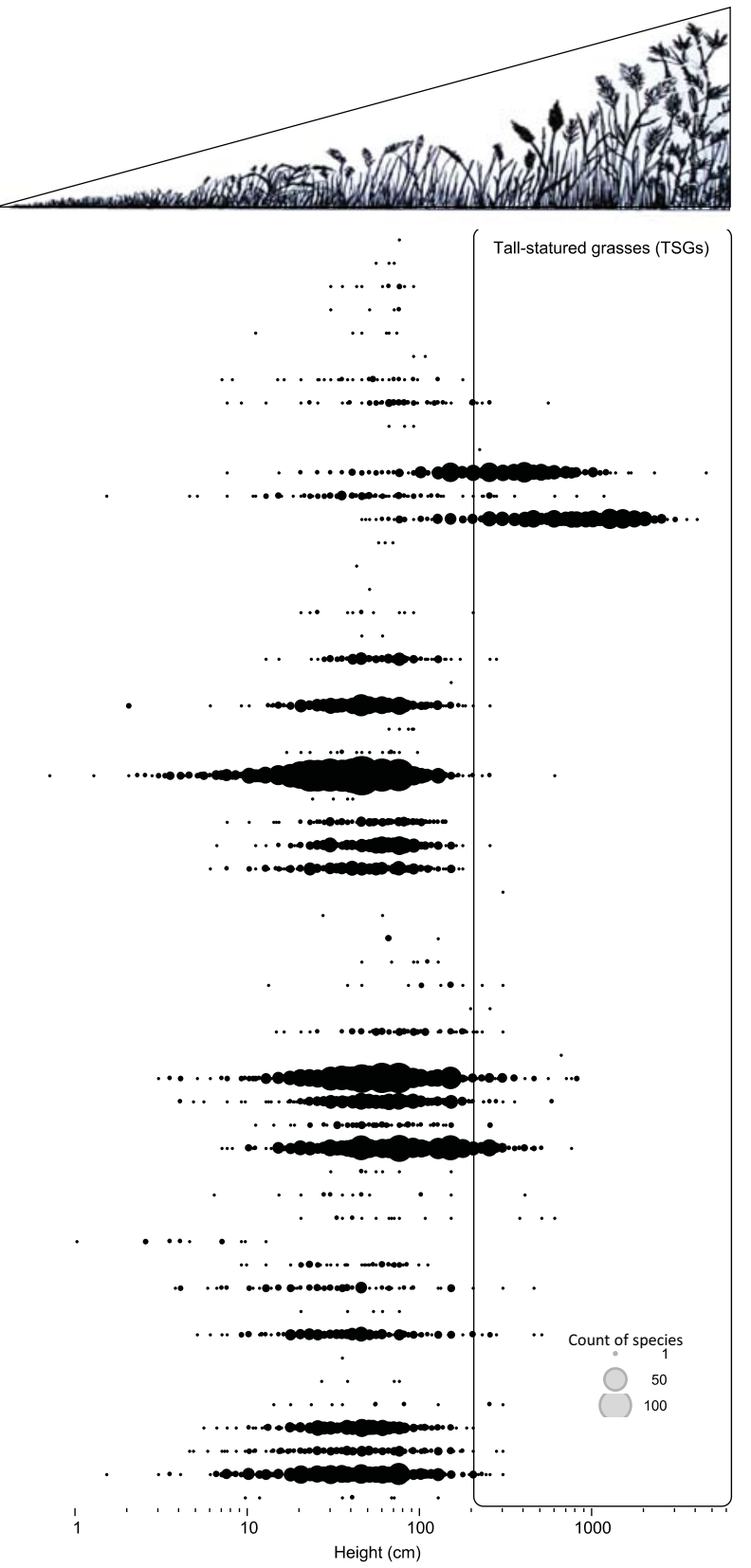

number of species. Data were retrieved from Kew's GrassBase (http://www.kew.org/data/grasses-db.html) for 10,818 species. Species that are unplaced in a tribe are shown as incertae sedis for that subfamily. Woody bamboos (tribes Arundinarieae and Bambuseae) are marked with an asterisk. Figure generated using Tableau V 10.0

(http://davesgarden.com/guides/pf), arguably the most comprehensive global database of garden plants. While it would have been ideal to use quantitative sale 
Table 1 Typical features of tall-statured grasses (TSGs) that confer a high likelihood of causing widespread invasions and severe environmental impact

\begin{tabular}{|c|c|c|c|}
\hline & $\begin{array}{l}\text { Features typical of } \\
\text { TSGs }\end{array}$ & $\begin{array}{l}\text { Implications for invasiveness/ } \\
\text { impact }\end{array}$ & Examples \\
\hline \multirow[t]{2}{*}{ 1. Biomass production } & Statured architecture & $\begin{array}{l}\text { High light capture, so likely to } \\
\text { outcompete shorter vegetation }\end{array}$ & $\begin{array}{l}\text { Miscanthus sinensis (Tang et al. 1990); } \\
\text { Phragmites australis (Meyerson et al. 2000) }\end{array}$ \\
\hline & Fast growth rates & $\begin{array}{l}\text { Can outcompete neighbouring } \\
\text { species }\end{array}$ & Bamboos (Montti et al. 2014) \\
\hline \multirow[t]{4}{*}{$\begin{array}{l}\text { 2. Biomass } \\
\text { accumulation }\end{array}$} & Leaf litter build-up & $\begin{array}{l}\text { Suppress growth of neighbouring } \\
\text { plants }\end{array}$ & $\begin{array}{l}\text { Cortaderia jubata (Lambrinos 2000); } \\
\text { Cortaderia selloana (Domènech et al. 2006); } \\
\text { Miscanthus } \times \text { giganteus (Amougou et al. } \\
\text { 2012); Phragmites australis (Haslam 2010; } \\
\text { Holdredge and Bertness 2011) }\end{array}$ \\
\hline & \multirow[t]{2}{*}{$\begin{array}{l}\text { Chemically distinct leaf } \\
\text { litter }\end{array}$} & Reduced decomposition & $\begin{array}{l}\text { Bambusa spp. (O'Connor et al. 2000); } \\
\text { Phragmites australis (Meyerson et al. 2000) }\end{array}$ \\
\hline & & Alter nutrient cycling & $\begin{array}{l}\text { Cortaderia selloana (Domènech et al. 2006); } \\
\text { Phragmites australis (Meyerson et al. 2000); } \\
\text { Phyllostachys edulis (Song et al. 2017) }\end{array}$ \\
\hline & $\begin{array}{l}\text { Production of large } \\
\text { quantities of highly } \\
\text { flammable aboveground } \\
\text { biomass }\end{array}$ & $\begin{array}{l}\text { Alter the frequency and intensity } \\
\text { of fires }\end{array}$ & $\begin{array}{l}\text { Arundo donax (Herrera and Dudley 2003; } \\
\text { McWilliams 2004; Lambert et al. 2010; } \\
\text { Coffman et al. 2010); Andropogon gayanus } \\
\text { (Rossiter et al. 2003); Andropogon virginicus, } \\
\text { Hyparrhenia rufa, Melinis minutiflora, } \\
\text { Schizachyrium condensatum (Brooks et al. } \\
\text { 2004); bamboo (Jaiswal et al. 2002); } \\
\text { Cortaderia selloana (Bossard et al. 2000) }\end{array}$ \\
\hline \multirow[t]{5}{*}{$\begin{array}{l}\text { 3. Dual reproductive } \\
\text { modes }\end{array}$} & $\begin{array}{l}\text { Tall plants with seeds } \\
\text { held high up }\end{array}$ & Long range dispersal of seeds & $\begin{array}{l}\text { Cortaderia selloana (Drewitz and DiTomaso } \\
\text { 2004); Generally in plants (Thompson et al. } \\
\text { 1995); specifically for grasses (Linder et al. } \\
\text { 2018) }\end{array}$ \\
\hline & Dense root systems & Crowd out other vegetation & Phragmites australis (Meyerson 2000) \\
\hline & $\begin{array}{l}\text { Clonal networks leading } \\
\text { to greater resource } \\
\text { acquisition }\end{array}$ & $\begin{array}{l}\text { Ability to survive high stress } \\
\text { environments }\end{array}$ & $\begin{array}{l}\text { Gynerium sagittatum (de Kroon and Kalliola } \\
\text { 1995); clonal plants in general (Stueffer et al. } \\
\text { 1996; van Kleunen and Stuefer 1999) }\end{array}$ \\
\hline & $\begin{array}{l}\text { Clonal networks leading } \\
\text { to colonisation by } \\
\text { juvenile ramets into low } \\
\text { resource patches are } \\
\text { supported by older ones }\end{array}$ & $\begin{array}{l}\text { Ability to colonise stressful } \\
\text { environments }\end{array}$ & Phyllostachys edulis (Wang et al. 2016) \\
\hline & $\begin{array}{l}\text { High belowground } \\
\text { allocation/storage of } \\
\text { resources }\end{array}$ & $\begin{array}{l}\text { Ability to survive disturbance } \\
\text { and regenerate quickly, out- } \\
\text { competing neighbouring } \\
\text { vegetation }\end{array}$ & $\begin{array}{l}\text { Dendrocalamus strictus (Singh and Singh } \\
\text { 1999); Miscanthus spp. (Amougou et al. 2011) }\end{array}$ \\
\hline \multirow[t]{2}{*}{$\begin{array}{l}\text { 4. Anthropogenic } \\
\text { interest }\end{array}$} & Use as biofuel & $\begin{array}{l}\text { Increased dissemination, } \\
\text { propagule pressure, often in } \\
\text { large stands in climatically } \\
\text { suitable areas close to the } \\
\text { natural environment }\end{array}$ & $\begin{array}{l}\text { Arundo donax (Cosentino et al. 2006); } \\
\text { Miscanthus } \times \text { giganteus (Schnitzler and Essl } \\
\text { 2015); Miscanthus sinensis (Flory et al. 2012) }\end{array}$ \\
\hline & $\begin{array}{l}\text { Use in ornamental } \\
\text { horticulture } \\
\text { (particularly } \\
\text { landscaping) }\end{array}$ & $\begin{array}{l}\text { Increased dissemination, } \\
\text { propagule pressure, and } \\
\text { multiple foci for potential } \\
\text { invasions }\end{array}$ & $\begin{array}{l}\text { Arundo donax, Cortaderia selloana, Cenchrus } \\
\text { purpureus (Foxcroft et al. 2008); Cortaderia } \\
\text { selloana (Okada et al. 2007); bamboo } \\
\text { (Canavan et al. 2017b); Miscanthus sinensis } \\
\text { (Dougherty 2013) }\end{array}$ \\
\hline
\end{tabular}


and trade data from Dave's Garden as a proxy of propagule pressure, such data were only available for a small subset of species. We therefore confined the analyses to whether or not a species was present in Dave's Garden Plant Files.

When exploring the raw data, it was clear that the vast majority of TSGs were woody bamboos (tribes: Bambuseae and Arundinarieae; Fig. 2). Also, the percentage of TSGs that naturalised was greater than that of non-TSGs for woody bamboos and other grasses (i.e. non-bamboos and non-woody bamboos), although this pattern was not found when pooling all grasses together (a result of inequities in the proportions of the taxa which were TSGs; see Online Resource 4). For this reason, we conducted the remaining analyses on naturalisation incidence and extent (described below) separately for the set of woody bamboos and for the set of other grasses.

To assess whether naturalisation incidence was higher in TSGs than non-TSGs, we ran generalised linear mixed-effects models with a binomial error distribution (logistic regression), separately for woody bamboos and for other grasses, using the 'lme4' $\mathrm{R}$ package (Bates et al. 2015). The response variable was status (presence or absence) in the GloNAF database and the predictor variables were whether a species is a TSG or non-TSG, and whether a species was traded or not (as inferred from presence or absence in Dave's Garden Plant Files). To account for phylogenetic nonindependence of the species, we included genus (in the case of woody bamboos) and genus nested within tribe (in the case of other grasses) as random factor(s). This also provided an opportunity to test whether the 2 m cutoff was appropriate. We ran similar models with height (standardised to a mean of 0 and standard deviation of 1 ) as a continuous explanatory variable instead of stature as a binary variable (TSG or non-TSG).

To analyse extent of naturalisation (i.e. number of regions in the GloNAF database) we ran generalised linear mixed-effects models with a negative binomial error distribution, due to high incidence of zeros, separately for woody bamboos and for other grasses, using the 'glmmADMB' $\mathrm{R}$ package (Fournier et al. 2012). We used the same predictor variables and random factors as in the analysis of naturalisation incidence. Finally, we looked at the global geographic pattern of numbers of naturalised TSGs and of the proportion of TSGs among all naturalised grass species.

\section{Reviewing future risks}

To explore the threats of TSGs introduced to new regions, we reviewed risk assessments that have been completed in different parts of the world for our list of TSGs (See Online Resource 2 for details). We did this by searching (from May to July 2016) for primary literature and fact sheets on Scopus, ISI Web of Science and Google Scholar using the specific names of the TSG species/“tall grass" AND "risk assessment"/"risk analysis" as keywords. We collated all the risks assessments and then summarised the species for which assessments have been reported.

\section{Results}

TSG species

From the lists extracted from Kew's GrassBase, we removed 18 species that did not have names matching the World Checklist of Selected Plant Families or INBAR's global 2016 checklist, four unplaced species were kept in the list, and synonyms $(n=79)$ were updated accordingly to reflect current nomenclature. Of the remaining 10,818 grass species for which height data were available, 1136 species reach heights of $2 \mathrm{~m}$ or more, although 207 of these do not maintain their height independently and were classified as nonTSGs. This left 929 species (8.6\% of grass species) as TSGs for subsequent analysis (See Online Resource 1 for a complete list of species).

Among TSGs, the vast majority $(80.6 \%)$ are woody bamboos (tribes Arundinarieae and Bambuseae). The remaining 180 species of TSGs come from 21 tribes in 7 subfamilies (Fig. 2), many of which are important reed species, such as Burma reed (Neyraudia reynaudiana; Triraphideae), common reed (Phragmites australis; Molinieae), and giant reed (Arundo donax; Arundineae). Other TSGs include popular horticultural and biofuel species such as pampas grass (Cortaderia spp.; Danthonieae) and silver grass (Miscanthus sinensis; Andropogoneae). The TSG group also contains important food crops, in particular maize (Zea mays; Andropogoneae), pearl millet (Cenchrus americanus = Pennisetum glaucum; Paniceae), sorghum (Sorghum bicolor; Andropogoneae), and sugarcane (Saccharum spp.; Andropogoneae) (Fischer et al. 2014). With the exception of woody bamboos, TSGs 
are outliers in their respective tribes in terms of height, although the height distribution of all tribes appears to be roughly unimodal (Fig. 2).

Incidence and extent of naturalisation

The GloNAF database lists 1226 species in the grass family. We found overall a similar percentage of naturalised species among TSGs and among nonTSGs using the $2 \mathrm{~m}$ threshold, with 11.4 and $11.3 \%$ of species naturalised, respectively (Fig. 3). However, when considering woody bamboos alone, the percentage of naturalised TSGs is more than three times that of non-TSG bamboos, with 7.6 and $2.0 \%$ of species, respectively (Fisher's exact test: odds ratio $=4.1,95 \%$ confidence interval of $1.9-9.9, p<0.001)$. This is also the case among all other grasses (i.e. excluding woody bamboos), with 27.2 and $11.7 \%$, respectively (Fisher's exact test: odds ratio $=2.8,95 \%$ confidence interval of 2.0-4.0, $p<0.001$ ). The lack of contrast overall between TSGs and non-TSGs is because most TSGs are woody bamboos but fewer woody bamboos than other grasses have naturalised (Online Resource 4).

Among both woody bamboos and other grasses, species that are traded for ornamental horticulture have naturalised more often than non-horticultural species. Of the 1233 grass species listed in Dave's Garden Plant Files, 53.4\% are naturalised, while only $5.9 \%$ of the other 9585 grass species have naturalised. When the presence of a species in Dave's Garden Plant Files was accounted for in the analysis, tall stature had a significant, positive effect on naturalisation incidence of other grasses (Table 2a). This was not the case for woody bamboos. However, when a similar model was run with height as a continuous variable height had a significant, positive effect on naturalisation incidence for both woody bamboos and other tall grasses (Table 2a).

Of the subset of 1226 grass species (of all tribes) that have naturalised somewhere, 384 species have naturalised in only one region, whereas some species (e.g. Eleusine indica, a non-TSG) have naturalised in 309 regions according to the GloNAF database. On average, when considering grasses together, TSGs and non-TSGs have naturalised in similar numbers of regions (Online Resource 4; Wilcoxon test: $\mathrm{W}=56,274, p=0.368)$. When considering woody bamboos alone, and accounting for the strong positive effect of presence in the horticultural trade, the extent of naturalisation was still significantly positively associated with tall stature (Table 2b). Indeed, woody bamboo TSGs have naturalised in up to 101 regions (e.g. Bambusa vulgaris being the most widespread species) whereas the 8 non-TSG woody bamboos have naturalised in at most five regions (Online Resource 1). However, this effect of stature on naturalisation extent was not found for other grasses.

The regions with the highest number of recorded naturalised alien grasses (irrespective of whether they are a TSG or not) are the southern United States, tropical South America, Hawaii, parts of tropical Africa, Madagascar, Indonesia and New Zealand (Fig. 4a, Table 3). However, the pattern is strikingly different when using the proportion of TSGs among all naturalised grasses (in part because species richness is affected by differences in sizes of the regions). This relative measure identifies a marked hot spot of TSGs in tropical Africa (especially islands in the Western Indian Ocean), where the proportions in most countries range between 30-70\% and even more (Fig. 4b). The Caribbean is a second hotspot (Fig. 4b).

Reviewing risks

We found 127 risk assessments that have been completed for 64 TSG species. Of these, 55 assessments $(43 \%)$ on 23 species had an outcome indicating a high risk of invasion or recommended that further introductions should be rejected in the region evaluated (Table 4; See Online Resource 3 for full list). More than a third (38\%) of the risk assessments were conducted on 32 woody bamboo species (all of which are TSGs). However, woody bamboos generally received lower risk scores than other TSGs, with only three risk assessments scoring high risk for two species, and five assessments called for an introduction to be rejected on five species.

The most widely used risk assessment scheme was the Hawaiian Weed Risk Assessment (H-WRA), which has been applied in 60 assessments, followed by the Australian Weed Risk Assessment (A-WRA) with nine assessments. Another 16 variant risk assessment frameworks were used. The following species had the greatest number of completed risk assessments: Arundo donax (12), Miscanthus sinensis (8), Cortaderia jubata (7), Sorghum bicolor (7) and Cortaderia selloana (7). Based on the results of the risk assessments, the species with a high potential to 
Fig. 3 The proportion of grass species that have naturalised globally, by height group, for $\mathbf{a}$ all grasses, $\mathbf{b}$ woody bamboos only and $\mathbf{c}$ all grasses excluding woody bamboos. Data were retrieved from the GloNAF database [see van Kleunen et al. (2015)]. The proportion of tall-statured grasses (TSGs; those that are $2 \mathrm{~m}$ in height or greater) and non-TSGs (less than $2 \mathrm{~m}$ in height) that have naturalised vary between woody bamboos and other grasses. The white bars indicate $95 \%$ confidence intervals. There is a very large number of tall-statured non-naturalised bamboos. See Online Resource 4 for the raw data

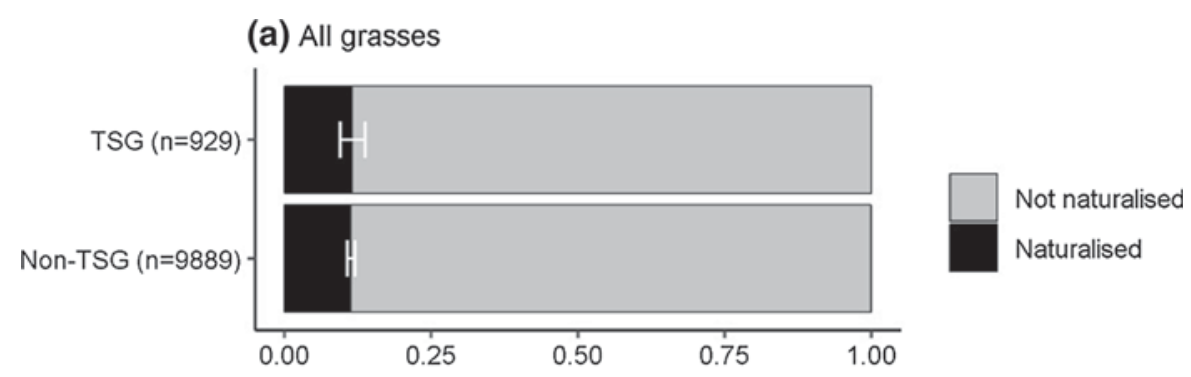

(b) Woody bamboos

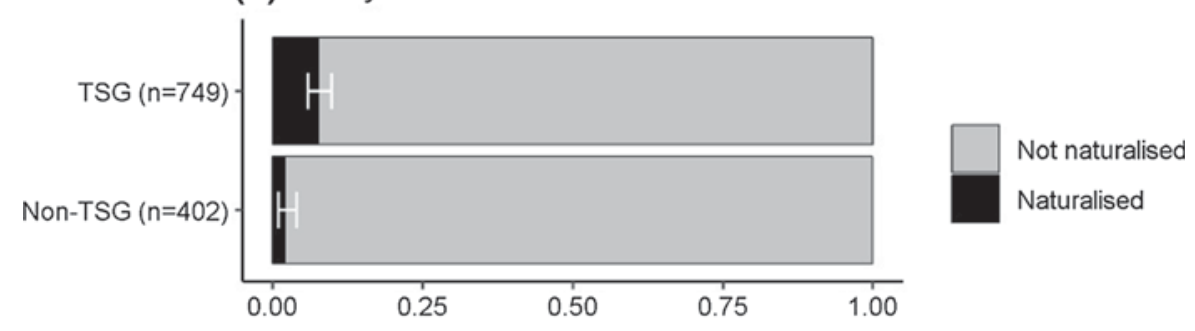

(c) Non-bamboo grasses

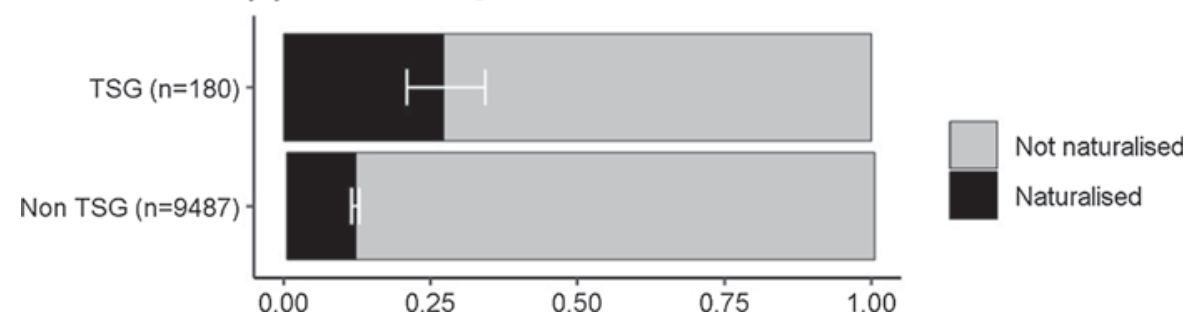

cause negative impacts were Arundo donax, Cortaderia jubata, Echinochloa pyramidalis and Phragmites australis (Table 4).

Several intended uses for TSGs were identified as generating heightened risk due to the massive propagule pressure associated with such usage: of the risk assessments completed, $37 \%$ were for the introduction of ornamental horticulture and food crops species and $28 \%$ for biofuels and bioenergy purposes. The purpose of introduction was unspecified in $42 \%$ of assessments (see Online Resource 3 for more details).

\section{Discussion}

Tall-statured grass (TSG) groups with high impact

Woody bamboos (tribes Arundinarieae and Bambuseae) are among the tallest grasses and make up the majority of TSG species (Fig. 2). They have some of the most varied uses of any plant group and are widely used in agroforestry, medicine, food, fodder, ornamentation and, more recently, phytoremediation and bioenergy, and for these reasons they have been distributed and cultivated around the world (Soderstrom and Calderon 1979; Farrelly 1984; Liese and Köhl 2015; Canavan et al. 2017b). According to Canavan et al. (2017b), at least 232 (14\%) of all 1662 bamboo species have been introduced beyond their native range. However, only 12 species are recorded as invasive (i.e. spreading), fewer than other grass tribes and less than other TSGs. Although they have been widely introduced, bamboos have lower invasion rates but have high levels of environmental impacts in disturbed forests, both in the native and alien range (O'Connor et al. 2000; Teixeira and Oatham 2001; Lima et al. 2012; Xu et al. 2014; Rother et al. 2016; Canavan et al. 2018a). This is attributed to the high competitive ability of certain bamboo species and their capacity to rapidly colonise open space in disturbed 
Table 2 The influence of plant stature and garden use status on global naturalisation of woody bamboos and other grasses. Plant height was analysed both as a factor (i.e. tall-statured grass (TSG) of stature $\geq 2 \mathrm{~m}$ vs. non-TSGs) and as a continuous variable (results shown in italics). Garden-use status was binary (presence/absence in Dave's Garden Plant Files database; http://davesgarden.com/guides/pf). Global naturalisation was measured as (a) naturalisation incidence outside the native range (expressed as being naturalised in at least one region, yes or no), and (b) naturalisation extent (number of regions where the species is recorded as naturalised). To assess whether naturalisation incidence or naturalisation extent related to stature and to the presence in Dave's Garden database,

\begin{tabular}{|c|c|c|c|c|c|c|c|c|}
\hline \multirow[t]{2}{*}{ Explanatory variable } & \multicolumn{4}{|c|}{ Woody bamboos $(n=1162)$} & \multicolumn{4}{|c|}{ Other grasses $(n=9674)$} \\
\hline & Estimate & SE & $\mathrm{z}$ & $p$ & Estimate & SE & $\mathrm{z}$ & $p$ \\
\hline \multicolumn{9}{|c|}{ (a) Global naturalisation incidence (yes/no) } \\
\hline \multirow[t]{2}{*}{ Intercept } & -5.365 & 0.533 & -10.06 & $<0.001$ & -3.026 & 0.181 & -16.74 & $<0.001$ \\
\hline & -5.101 & 0.422 & -12.087 & $<0.001$ & -3.023 & 0.187 & -16.15 & $<0.001$ \\
\hline Stature (TSG/non-TSG) & 0.4803 & 0.470 & 1.021 & 0.307 & 0.931 & 0.242 & 3.85 & $<0.001$ \\
\hline Height (continuous) & 0.431 & 0.143 & 3.021 & 0.0025 & 0.159 & 0.036 & 4.37 & $<0.001$ \\
\hline \multirow[t]{2}{*}{ Recorded in Dave's Garden (yes/no) } & 3.843 & 0.428 & 8.979 & $<0.001$ & 3.204 & 0.092 & 34.99 & $<0.001$ \\
\hline & 3.839 & 0.427 & 8.983 & $<0.001$ & 3.188 & 0.092 & 34.79 & $<0.001$ \\
\hline Random factors & SD & & & & SD & & & \\
\hline \multirow[t]{2}{*}{ Genus } & 0.6864 & & & & 0.9504 & & & \\
\hline & 0.6854 & & & & 0.9491 & & & \\
\hline \multirow[t]{2}{*}{ Tribe } & not applicable & & & & 0.5826 & & & \\
\hline & & & & & 0.6278 & & & \\
\hline \multirow[t]{2}{*}{ Explanatory variable } & \multicolumn{4}{|c|}{ Woody bamboos $(n=67)$} & \multicolumn{4}{|c|}{ Other grasses $(n=1162)$} \\
\hline & Estimate & SE & $\mathrm{z}$ & $p$ & Estimate & SE & $\mathrm{z}$ & $p$ \\
\hline \multicolumn{9}{|c|}{ (b) Global naturalisation extent (number of regions where naturalised) } \\
\hline Intercept & -0.612 & 0.751 & -0.81 & 0.415 & 1.583 & 0.142 & 11.13 & $<0.001$ \\
\hline Stature (TSG/non-TSG) & 1.139 & 0.511 & 2.23 & 0.026 & -0.147 & 0.242 & -0.61 & 0.54 \\
\hline Recorded in Dave's Garden (yes/no) & 1.340 & 0.655 & 2.05 & 0.041 & 1.518 & 0.080 & 18.92 & $<0.001$ \\
\hline Random factors & $\mathrm{SD}$ & & & & $\mathrm{SD}$ & & & \\
\hline Genus & 0.3947 & & & & 0.7103 & & & \\
\hline Tribe & not applicable & & & & 0.4037 & & & \\
\hline
\end{tabular}

we ran generalised linear mixed-effects models with a binomial error distribution or a negative binomial error distribution, respectively. To account for phylogenetic non-independence of nested within tribe (for other grasses) as random factor(s). For naturalisation incidence, we ran similar models with height (standardised to a mean of 0 and standard deviation of 1) as a continuous explanatory variable instead of stature, the results are shown in italics. Note that woody bamboos refers to species within the Bambuseae and Arundinarieae tribe, and non-bamboo grasses include all other species in the family Poaceae the species, we included genus (for woody bamboos) or genus 
(a)

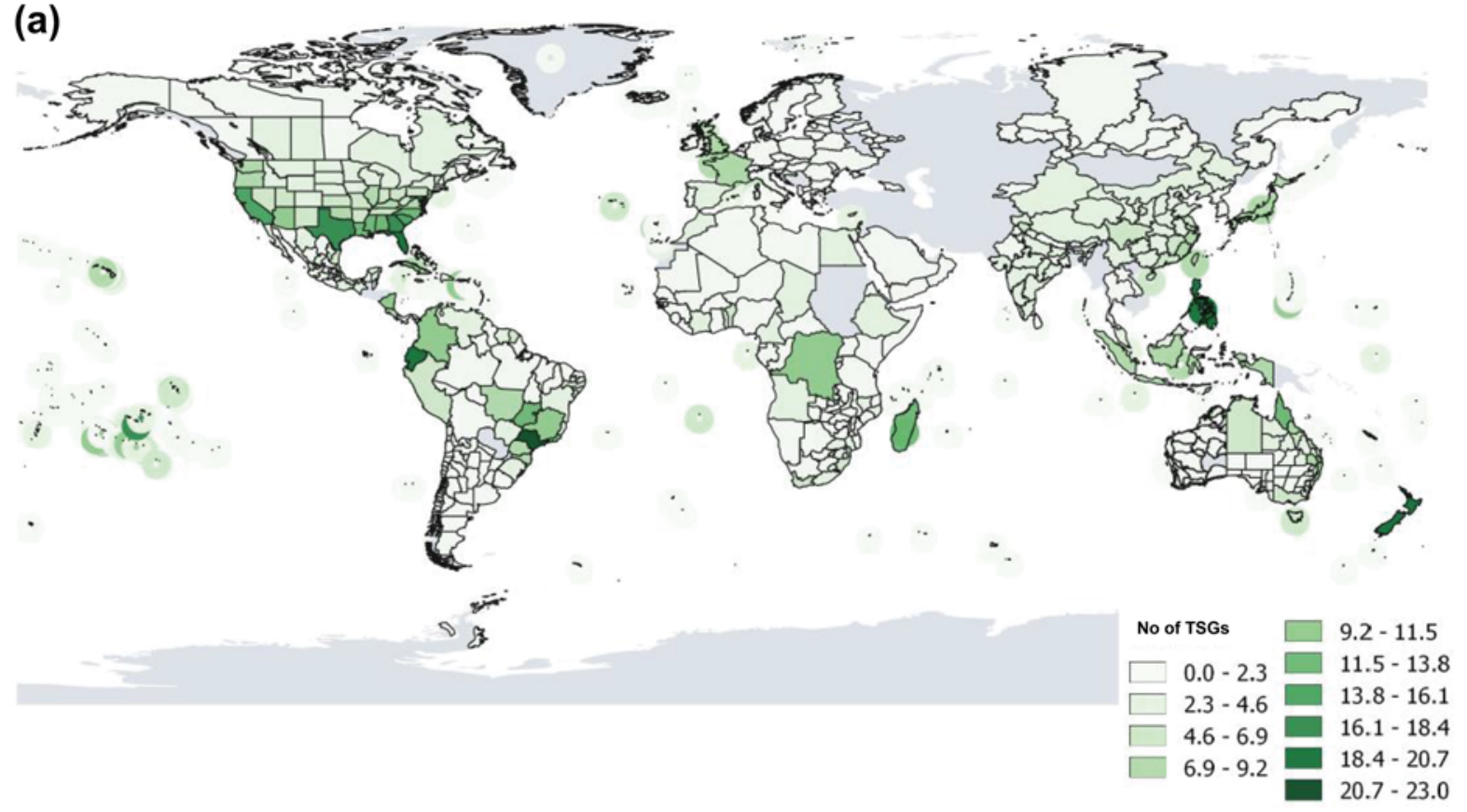

(b)

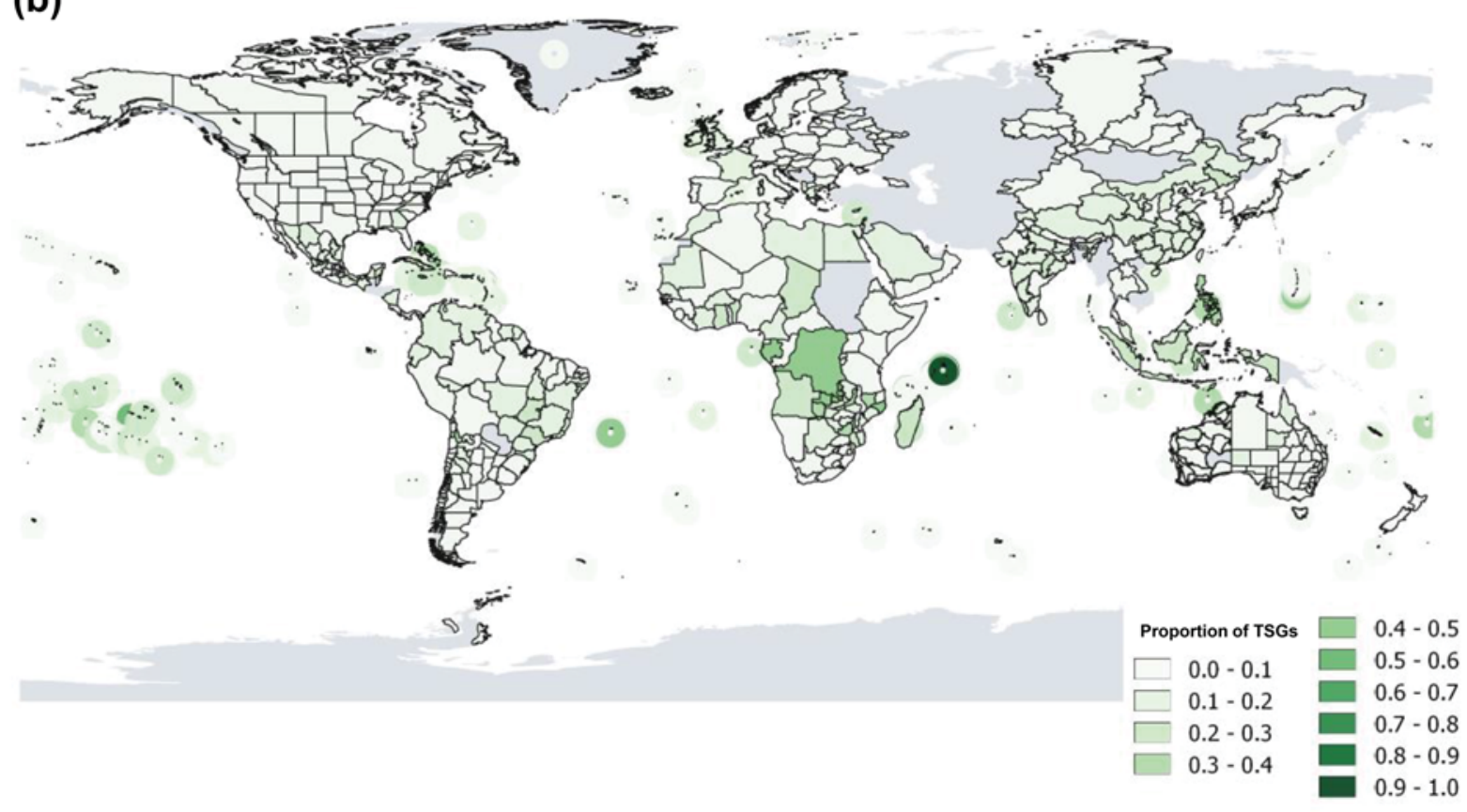

Fig. 4 a Numbers of naturalised tall-statured grass species (TSGs) and $\mathbf{b}$ their proportions among all naturalised grass species (b) in 843 GloNAF regions of the world (see van Kleunen et al. (2015) for description of regions and data acquisition). Darker colours indicate a greater number of naturalised TSGs or that naturalised TSGs represent a greater proportion of all naturalised grasses, respectively. Regions in grey are missing data 


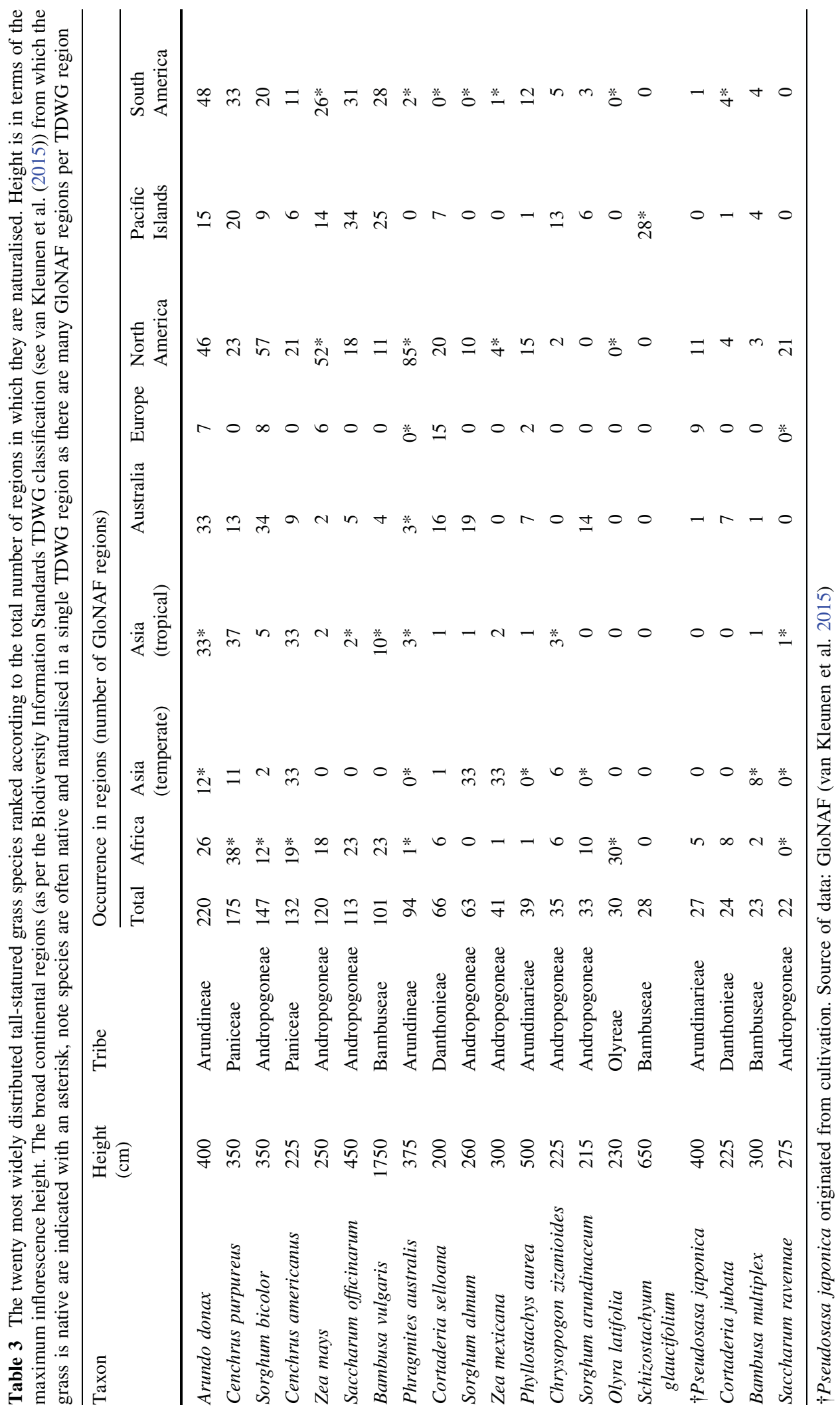


Table 4 Risk assessments completed for tall-statured grass species

\begin{tabular}{|c|c|c|c|c|c|c|c|c|c|c|}
\hline Species & Common name & RAs & Reg & Accept & LR & IR & HR & Reject & $\mathrm{EF}$ & Other \\
\hline Andropogon bicornis L. & $\begin{array}{l}\text { West Indian foxtail } \\
\text { grass }\end{array}$ & 1 & 1 & & & & 1 & & & \\
\hline Andropogon gayanus Kunth & Gamba grass & 1 & 1 & & & & & 1 & & \\
\hline Arundo donax $\mathrm{L}$. & Giant reed & 12 & 9 & & & & 2 & 7 & & 1 \\
\hline Bambusa bambos (L.) Voss & Thorny bamboo & 1 & 1 & & & & & & 1 & \\
\hline Bambusa chungii McClure & $\begin{array}{l}\text { Emperor's blue } \\
\text { bamboo }\end{array}$ & 1 & 1 & & 1 & & & & & \\
\hline Bambusa glaucophylla Widjaja & $\begin{array}{l}\text { Malay dwarf } \\
\text { bamboo }\end{array}$ & 1 & 1 & & 1 & & & & & \\
\hline Bambusa lako Widjaja & Timor black bamboo & 2 & 1 & & 1 & & & & 1 & \\
\hline Bambusa multiplex (Lour.) Raeusch. ex Schult. & $\begin{array}{l}\text { Chinese dwarf } \\
\text { bamboo }\end{array}$ & 3 & 2 & 1 & & & & 1 & 1 & \\
\hline Bambusa oldhamii Munro & Oldhamii bamboo & 2 & 1 & 1 & & & & & 1 & \\
\hline Bambusa oliveriana Gamble & Bush bamboo & 1 & 1 & & 1 & & & & & \\
\hline Bambusa pervariabilis McClure & Puntingpole bamboo & 1 & 1 & & 1 & & & & & \\
\hline Bambusa textilis McClure & Weaver's bamboo & 1 & 1 & & 1 & & & & & \\
\hline Bambusa tuldoides Munro & $\begin{array}{l}\text { Buddha Belly } \\
\text { bamboo }\end{array}$ & 1 & 1 & & & & & & 1 & \\
\hline Bambusa vulgaris Schrad. & Common bamboo & 3 & 3 & & 1 & & & & 2 & \\
\hline $\begin{array}{l}\text { Schizostachyum pergracile (Munro) } \\
\text { R.B.Majumdar }\end{array}$ & Tinwa bamboo & 1 & 1 & & 1 & & & & & \\
\hline \multicolumn{11}{|l|}{ (= Cephalostachyum pergracile Munro) } \\
\hline $\begin{array}{l}\text { Chimonobambusa quadrangularis (Fenzi) } \\
\text { Makino }\end{array}$ & Square bamboo & 1 & 1 & & & & & 1 & & \\
\hline Chrysopogon zizanioides (L.) Roberty & Vetiver grass & 4 & 3 & 2 & 1 & & 1 & & & \\
\hline Cortaderia jubata (Lem.) Stapf & Purple pampas grass & 7 & 3 & & & & 3 & 3 & & 1 \\
\hline $\begin{array}{l}\text { Cortaderia selloana (Schult.) Aschers. \& } \\
\text { Graebn. }\end{array}$ & Silver pampas grass & 6 & 4 & & 1 & & 2 & 2 & & 1 \\
\hline Cymbopogon martini (Roxb.) W.Watson & $\begin{array}{l}\text { Ginger grass, } \\
\text { Palmarosa }\end{array}$ & 1 & 1 & & 1 & & & & & \\
\hline $\begin{array}{l}\text { Dendrocalamus asper (Schult.) Backer ex } \\
\text { K.Heyne }\end{array}$ & Giant bamboo & 2 & 2 & & 1 & & & & 1 & \\
\hline Dendrocalamus brandisii (Munro) Kurz & Velvetleaf bamboo & 1 & 1 & & & & & & 1 & \\
\hline Dendrocalamus sikkimensis Gamble ex Oliver & $\begin{array}{l}\text { Philippine sweet } \\
\text { shoot bamboo }\end{array}$ & 1 & 1 & & 1 & & & & & \\
\hline Dendrocalamus strictus (Roxb.) Nees & Male bamboo & 1 & 1 & & & & & & 1 & \\
\hline Drepanostachyum falcatum (Nees) P.C.Keng & Blue bamboo & 1 & 1 & 1 & & & & & & \\
\hline $\begin{array}{l}\text { Drepanostachyum khasianum (Munro) } \\
\text { P.C.Keng }\end{array}$ & Khasia bamboo & 1 & 1 & & 1 & & & & & \\
\hline $\begin{array}{l}\text { Echinochloa pyramidalis (Lam.) Hitchc. \& } \\
\text { Chase }\end{array}$ & Antelope grass & 2 & 1 & & & & 1 & & & 1 \\
\hline Fargesia fungosa T.P.Yi & Chocolate bamboo & 1 & 1 & & 1 & & & & & \\
\hline Fargesia nitida (Mitford) Keng f. ex T.P.Yi & $\begin{array}{l}\text { Blue Fountain } \\
\text { bamboo }\end{array}$ & 1 & 1 & 1 & & & & & & \\
\hline Gigantochloa apus (Schult.) Kurz & Gigantochloa & 2 & 2 & & 1 & & & & 1 & \\
\hline Gigantochloa atroviolacea Widjaja & $\begin{array}{l}\text { Sweet bamboo, } \\
\text { pring legi }\end{array}$ & 1 & 1 & & 1 & & & & & \\
\hline
\end{tabular}


Table 4 continued

\begin{tabular}{|c|c|c|c|c|c|c|c|c|c|c|}
\hline Species & Common name & RAs & $\operatorname{Reg}$ & Accept & LR & IR & HR & Reject & $\mathrm{EF}$ & Other \\
\hline Gigantochloa atter (Hassk.) Kurz & Sweet bamboo & 1 & 1 & & 1 & & & & & \\
\hline Gigantochloa robusta Kurz & Robust bamboo & 1 & 1 & & 1 & & & & & \\
\hline Guadua angustifolia Kunth & $\begin{array}{l}\text { Guadua, Columbian } \\
\text { thorny bamboo }\end{array}$ & 1 & 1 & & & & & & 1 & \\
\hline Hymenachne amplexicaulis (Spreng.) Zuloaga & Hymenachne & 1 & 1 & & & & & 1 & & \\
\hline $\begin{array}{l}\text { Miscanthus floridulus (Labill.) Warb. ex } \\
\text { K.Schum. \& Lauterb. }\end{array}$ & Giant miscanthus & 1 & 1 & & & & 1 & & & \\
\hline Miscanthus sinensis Andersson & Chinese silvergrass & 8 & 7 & & 1 & 1 & & 3 & & 3 \\
\hline $\begin{array}{l}\text { Miscanthus } \times \text { giganteus J.M.Greef \& Deuter } \\
\text { ex Hodk. \& Renvoize }\end{array}$ & Giant miscanthus & 3 & 1 & 3 & & & & & & \\
\hline Nastus elatus Holttum & $\begin{array}{l}\text { New Guinea edible } \\
\text { bamboo }\end{array}$ & 1 & 1 & & 1 & & & & & \\
\hline $\begin{array}{l}\text { Neyraudia reynaudiana (Kunth) Keng ex } \\
\text { Hitchcock }\end{array}$ & Burma reed & 3 & 1 & & & & 2 & 1 & & \\
\hline $\begin{array}{l}\text { Otatea acuminata (Munro) C.E.Calderon \& } \\
\text { T.R.Soderstrom (= Otatea aztecorum) }\end{array}$ & $\begin{array}{l}\text { Mexican weeping } \\
\text { bamboo }\end{array}$ & 1 & 1 & & 1 & & & & & \\
\hline $\begin{array}{l}\text { Cenchrus americanus }(\mathrm{L} .) \text { Morrone } \\
\text { (= Pennisetum glaucum (L.) R.Br.) }\end{array}$ & Pearl millet & 1 & 1 & & 1 & & & & & \\
\hline $\begin{array}{l}\text { Cenchrus macrourus (Trin.) Morrone } \\
\text { (= Pennisetum macrourum Trin.) }\end{array}$ & African feathergrass & 1 & 1 & & & & & 1 & & \\
\hline $\begin{array}{l}\text { Cenchrus purpureus (Schumach.) Morrone } \\
\text { (= Pennisetum purpureum Schumach.) }\end{array}$ & Elephant grass & 5 & 3 & & & & & 5 & & \\
\hline Phragmites australis (Cav.) Trin. ex Steud. & Common reed & 4 & 3 & & & & & 1 & & 3 \\
\hline Phyllostachys aurea Rivière \& C.Rivière & Golden bamboo & 4 & 3 & & & & 2 & 1 & 1 & \\
\hline Phyllostachys aureosulcata McClure & $\begin{array}{l}\text { Yellow groove } \\
\text { bamboo }\end{array}$ & 1 & 1 & & & & & & 1 & \\
\hline Phyllostachys nigra (Lodd.) Munro & Black & 2 & 2 & & & & 1 & 1 & & \\
\hline Pseudosasa japonica (Steud.) Makino & Arrow bamboo & 1 & 1 & & & & & 1 & & \\
\hline Saccharum arundinaceum Retz. & Plume Grass & 1 & 1 & 1 & & & & & & \\
\hline Saccharum officinarum $\mathrm{L}$. & Sugarcane & 3 & 2 & 2 & & & & 2 & & \\
\hline Saccharum ravennae (L.) Murr. & Ravenna Grass & 1 & 1 & & & & & 1 & & \\
\hline Saccharum spontaneum $\mathrm{L}$. & Wild sugarcane & 1 & 1 & & & & 1 & & & \\
\hline Schizostachyum brachycladum (Kurz) Kurz & Sacred Bali bamboo & 1 & 1 & & 1 & & & & & \\
\hline Schizostachyum glaucifolium (Rupr.) Munro & Hawaiian bamboo & 1 & 1 & & 1 & & & & & \\
\hline Sorghum bicolor (L.) Moench & Sweet Sorghum & 8 & 4 & 2 & 1 & & 2 & 1 & & 1 \\
\hline Zea mays $\mathrm{L}$. & Corn & 3 & 2 & 1 & & & & & 2 & \\
\hline
\end{tabular}

Number of risk assessments completed (RAs), number of regions evaluated (Reg), and the outcome of the evaluation are shown for each species; low risk (LR), intermediate risk (IR), high risk (HR), reject, evaluate further (EF) and other classification (e.g. prohibit for importation). See Online Resource 3 for a detailed list of all assessments

including Arundo donax and Phragmites australis (Lambert et al. 2010). Their presence and growth in ecosystems have important consequences for the structure and composition of their communities (Chambers et al. 1999; Meyerson et al. 2000;
Meyerson 2000; Holmes et al. 2005; Richardson et al. 2007a; Packer et al. 2017). In particular, invasive reeds efficiently exploit space and nutrients, allowing them to take advantage of natural and human-induced 
disturbances (Meyerson et al. 1999; Canavan et al. 2018b).

Tall-statured grass species (e.g. Cortaderia jubata, Cortaderia selloana, Miscanthus sinensis, Panicum virgatum) are also widely used for ornamental horticulture and bioenergy production. Many species used for this purpose escape from cultivation and spread into natural areas (Lambrinos 2000; Quinn et al. 2010; Schnitzler and Essl 2015). Interestingly, food crop TSGs (e.g. maize, sugarcane, pearl millet, sorghum), tend not to be invaders although they are widely propagated making up a vast component of landscapes altered by humans for agricultural purposes around the world, and they are very commonly planted as hybrids.

Extent and incidence of naturalisation of TSGs

Although we did not find that all models yielded a significant effect of stature, we did show that TSG categorisation is relevant with respect to probability for naturalisation. Specifically, we found that stature is associated with naturalisation success in grasses, but only when woody bamboos are excluded (Table 2). While stature is unlikely the proximate factor driving naturalisation, naturalisation patterns support the notion that being a TSG contributes to invasion potential. In agreement with other studies, we also found that the presence in horticultural trade is an important correlate of both naturalisation incidence and extent (Dehnen-Schmutz et al. 2007; van Kleunen et al. 2007, 2018; Pyšek et al. 2010). We also found that TSGs seem to have naturalised more on islands, probably due to the long history of bamboos being widely introduced and cultivated on islands along early trade routes (Canavan et al. 2017b).

\section{Competitive features of TSGs}

The heights obtained by TSGs (including bamboos) result in unique traits that can confer a competitive advantage over other co-occurring vegetation, including lignified stalks, production of large amounts of biomass (often at a rate faster than woody shrubs and trees; Linder et al. (2018)), formation of dense monospecific stands and extensive root and rhizome systems (See Table 1). Although these traits are not unique to TSGs and are present in other plant groups including shorter grasses, the combination of these traits enables some TSGs to have increased impacts.
Tall-statured grasses are also often the dominant components of the vegetation communities in ecosystems where they occur and thus have a strong effect on ecosystem functioning. As such, they have impacts at different trophic levels when they become invasive (Gordon-Gray and Ward 1971; Onimaru and Yabe 1996; Larpkern et al. 2011; Pagad 2016; MacedaVeiga et al. 2016). For example, the accumulation of dead biomass creates thick litter mats that can suppress the growth of emerging plants over time (Haslam 2010; Amougou et al. 2012; Rohani et al. 2014). The increase of litterfall, and therefore standing biomass, can also lead to changes in fire regimes through increased fuel loads which can inflict ecosystem-level changes, including transformed nutrient cycling and increased susceptibility of the ecosystem to further invasion (Rieger and Kreager 1989; Dwire and Kauffman 2003; Herrera and Dudley 2003; Brooks et al. 2004).

For most TSGs, vegetative growth is both a crucial competitive mechanism and a reproductive strategy for dispersal with tillers, shoots, ramets, rhizomes, stolons or fallen stems forming clonal networks (Wang et al. 2017). The connectivity of biomass between stands has many advantages: greater resource acquisition and sharing (de Kroon and Kalliola 1995; Stueffer et al. 1996; van Kleunen and Stuefer 1999); allowing invasion into closed canopies or low resource-patches (Welker and Briske 1992; Wang et al. 2016); and allowing the storage of resources (Grace 1993). The increased amount of below-ground vegetative biomass of TSGs, compared to shorter grasses and other plants like trees, likely gives populations added resilience to disturbances and provides a greater capacity for energy storage.

Sexual reproduction and seed dispersal is not a prerequisite for the spread of many TSGs (Ahmad et al. 2008; Hardion et al. 2012; Canavan et al. 2017a). Clonal TSGs use stem-derived spacers such as underground rhizomes or above-ground stolons to disperse which can be further aided by anthropogenic activities such as the movement of TSGs for ornamental horticulture and other purposes (SFAPRC 2006; Isagi et al. 2016). The ability of some TSGs to successfully colonise a wide variety of environmental gradients and yet have such low genetic diversity may also indicate that other important mechanisms are implicated, such as increased phenotypic plasticity in response to environmental changes (Canavan et al. 2017a). 
Invasive clonal plants like Arundo donax may possess a 'general-purpose-genotype', i.e. a genotype that allows for phenotypic plasticity and thus adaptation to a wide range of conditions (Van Doninck et al. 2002). Further, many TSGs have an allopolyploid origin and incorporate high genetic diversity in their genomes (Soltis and Soltis 2000).

Although vegetative growth clearly carries several advantages for the establishment of TSGs, this mode of dispersal alone has limitations. When TSGs can also reproduce sexually they have the added advantage of being able to achieve long-range dispersal independently (e.g. without the need for disturbance or human-facilitation) into adventive ranges. Sexual reproduction also produces genetic diversity and increases the opportunities for naturalisation and eventually adaptation to new habitats and ranges (Colautti and Lau 2015). Increased height can also be a competitive advantage in seed dispersal by wind, as pollen and seeds can travel above the canopy and cover long distances (Thomson et al. 2011). A number of TSGs have been found to disperse widely via seed production (Quinn et al. 2010; Ecker et al. 2015), but can also invade new ranges through the distribution of seeds (Chambers et al. 1999; Belzile et al. 2010; McCormick et al. 2010; Kettenring et al. 2011; Bonnett et al. 2014).

\section{Risks of invasion and impacts}

We found that a majority of risk assessments that have evaluated TSGs have been for horticultural introductions and more recently for bioenergy projects (Scurlock et al. 2000; Blanchard et al. 2017; Lieurance et al. 2018). Since TSGs are the grasses most often selected for bioenergy and biofuel production, this usage category will probably continue to drive future introductions from the group (Cousens 2008; Gordon et al. 2011; Hartman et al. 2011; Amougou et al. 2011; Jung et al. 2015; Smith et al. 2015; Corneli et al. 2016). Potential bioenergy TSG crops tend to receive higher risk scores than TSGs selected for other uses (See Online Resource 3). The most commonly mentioned candidates for biofuels include Arundo donax, Cenchrus purpureus (= Pennisetum purpureum), Miscanthus $\times$ giganteus (importantly neither parental species grows to $\geq 2 \mathrm{~m}$, indicating selection for greater height), Saccharum spp., as well as Panicum virgatum, (although just short of the $2 \mathrm{~m}$ threshold).
The high risk of biofuel-selected species is in line with previous studies; a comprehensive analysis by Buddenhagen et al. (2009) found that biofuel species are two to four times more likely to establish and become invasive than species introduced to Hawaii for other purposes.

An additional risk associated with biofuel and bioenergy crops is the intention to develop more robust and vigorous cultivars through genetic manipulation to produce crops that yield more biomass (Bouton 2007). Many of the selected traits overlap with known weedy attributes, such as: (1) fast growth rates; (2) high seed production; (3) wide range of climatic tolerance; (4) adaptability to a wide range of environmental conditions; and (5) few herbivores, pests and diseases in receiving ecosystems (IUCN 2009; Richardson and Blanchard 2011; Flory et al. 2012). In general, the high levels of domestication and breeding of TSGs, both historically and currently, have likely increased invasion risks of some species, as more robust cultivars have been and continue to be developed. Concerns have been expressed that, in general, current risk assessment frameworks and policies are limited in their ability to evaluate subspecies or lower taxa (e.g. cultivars, genotypes) and hybrids (Meffin 2013). For example, a cultivar of a species may perform very differently to the wild type of the species as it occurs in nature. Greater intraspecific diversity of a species has been found to be associated with an increased likelihood of naturalisation or establishment [e.g. South African Iridaceae species; van Kleunen et al. (2007)] and invasion or spread [e.g. bamboos and lineages of Phragmites; further; Meyerson et al. (2010), Kettenring et al. (2011), Meyerson (2013), Canavan et al. (2017a)], highlighting the need for better understanding of intraspecific dynamics. Even natural variations within a species can be problematic in this regard; this has been the case with $P$. australis where a certain haplotype (Saltonstall 2002) and smaller genome sizes (Pyšek et al. 2018) are more invasive than others (e.g. displacement of native haplotypes in North America). Invasive genotypes likely exist within other TSGs and other plant taxa more generally [e.g., Phalaris arundinacea; Lavergne and Molofsky (2007)], although they go unrecognised due to the difficulty in identifying intraspecific diversity. Additional criteria are needed to evaluate the invasion risks of subspecific or lower taxa, particularly to keep pace 
with the increasing selection and breeding of TSGs for biofuel and other uses surrounding high biomass yielding variations.

\section{The TSG concept and future directions}

While there is no clear break in the height distribution of grasses, TSGs are an important functional group as they cause distinct impacts and raise particular concerns for management and biosecurity. We suggest a number of directions that can be taken with the TSG group including: (1) studying subgroups of TSGs in particular biogeographical realms (e.g. Afrotropic TSGs), or habitat types in which they primarily occur (e.g. riparian, estuarine, or forest TSGs). Understanding the reasons for the differences between woody bamboos and other TSGs would be an important first step; (2) determining why different pathways and the traits selected in TSGs are associated with varying levels of risks. For example, trying to better understand why TSGs selected for biofuels are associated with high-risks, whereas food crops tend to be lowrisk; (3) reviewing the importance of TSGs in their native range for resisting invasions. For example, the composition of dominant native grasses have been found to be mediators of invasions as well as important predictors of the ability of a system to resist invasion (Tilman et al. 1997; Pokorny et al. 2005; Richardson et al. 2007b; Young et al. 2009; Wang et al. 2013); and (4) reviewing whether there is merit in expanding the functional group to encompass tall Poales [order of monocotyledons that include grasses, bromeliads and sedges] more generally, as many sedges and rushes employ similar mechanisms to disrupt and produce ecosystem-level changes through biomass production and accumulation [e.g. the removal of invasive Typha $\times$ glauca biomass increased native plant diversity along Great Lake coastal wetlands; Angeloni et al. (2006), Farrer and Goldberg (2009), Lishawa et al. (2015)].

In summary, we believe that the group of TSGs, including bamboos, are a useful functional group both for invasion science and management and that further research on the group, on both the biological reasons and the socio-economic imperatives that drive invasions, is warranted. Tall-statured grasses also provide an important counter-point to other analyses as to when generalisations can be made in invasion science (Kueffer et al. 2013).
Acknowledgements We thank the University of Sassari, Italy, for hosting the PhragNet 2016 planning meeting and creating the space that facilitated this manuscript. SC, DMR and JRUW acknowledge support from the DST-NRF Centre of Excellence for Invasion Biology and the National Research Foundation of South Africa (Grant 85417 to DMR). SC and JRUW acknowledge support from the South African National Department of Environment Affairs through its funding of the South African National Biodiversity Institute Invasive Species Programme. PP, JP, JČ, WYG and HS were supported by longterm research development Project RVO 67985939 (The Czech Academy of Sciences), Projects No. 14-36079G, Centre of Excellence PLADIAS and No. 14-15414S (Czech Science Foundation) and PP acknowledges support by Praemium Academiae award from The Czech Academy of Sciences. MvK and MW acknowledge support from the German Research Foundation (DFG, MvK: 264740629; MW: FZT 118), and FE was supported by the Austrian Science Foundation (FWF, Grant I2086-B16). JGP acknowledges support from the Faculty of Sciences and Environment Institute (Travel Grant 13116630) of The University of Adelaide.

\section{References}

Ahmad R, Liow P-S, Spencer DF, Jasieniuk M (2008) Molecular evidence for a single genetic clone of invasive Arundo donax in the United States. Aquat Bot 88:113-120

Amougou N, Bertrand I, Machet J-M, Recous S (2011) Quality and decomposition in soil of rhizome, root and senescent leaf from Miscanthus $\times$ giganteus, as affected by harvest date and N fertilization. Plant Soil 338:83-97

Amougou N, Bertrand I, Cadoux S, Recous S (2012) Miscanthus $\times$ giganteus leaf senescence, decomposition and $\mathrm{C}$ and N inputs to soil. GCB Bioenergy 4:698-707

Angeloni NL, Jankowski KJ, Tuchman NC, Kelly JJ (2006) Effects of an invasive cattail species (Typha $\times$ glauca) on sediment nitrogen and microbial community composition in a freshwater wetland. FEMS Microbiol Lett 263:86-92

Bai S, Zhou G, Wang Y, Liang Q, Chen J, Cheng Y, Shen R (2013) Plant species diversity and dynamics in forests invaded by Moso bamboo (Phyllostachys edulis) in Tianmu Mountain Nature Reserve. Biodivers Sci 21:288-295

Bates D, Mächler M, Bolker B, Walker S (2015) Fitting linear mixed-effects models using lme4. J Stat Softw 67:1-48

Belzile F, Labbe J, LeBlanc MC, Lavoie C (2010) Seeds contribute strongly to the spread of the invasive genotype of the common reed (Phragmites australis). Biol Invasions 12:2243-2250

Blanchard R, Kumschick S, Richardson DM (2017) Biofuel plants as potential invasive species: environmental concerns and progress towards objective risk assessment. In: Ruppel OC, Dix H (eds) Roadmap for sustainable biofuels in southern Africa: regulatory frameworks for improved development?, 1st edn. Nomos Verlagsgesellschaft mbH \& Co. KG, Baden-Baden, pp 47-60

Bonnett G, Kushner J, Saltonstall K (2014) The reproductive biology of Saccharum spontaneum L.: implications for 
management of this invasive weed in Panama. NeoBiota 20:61

Bossard CC, Randall JM, Hshousky MC (2000) Invasive plants of California's wildlands. University of California, Berkeley

Bouton JH (2007) Molecular breeding of switchgrass for use as a biofuel crop. Curr Opin Genet Dev 17:553-558

Brooks ML, D’Antonio CM, Richardson DM, Grace JB, Keeley JE, DiTomaso JM, Hobbs RJ, Pellant M, Pyke D (2004) Effects of invasive alien plants on fire regimes. Bioscience 54:677-688

Buddenhagen CE, Chimera C, Clifford P (2009) Assessing biofuel crop invasiveness: a case study. PLoS ONE 4:e5261

Canavan K, Paterson ID, Hill MP (2017a) Exploring the origin and genetic diversity of the giant reed, Arundo donax in South Africa. Invasive Plant Sci Manag 10:53-60

Canavan S, Richardson DM, Visser V, Roux JJL, Vorontsova MS, Wilson JRU (2017b) The global distribution of bamboos: assessing correlates of introduction and invasion. AoB Plants 9:plw078

Canavan S, Kumschick S, Le Roux JJ, Richardson DM, Wilson JRU (2018a) Does origin determine environmental impacts? Not for bamboos. Plants People Planet. https:// doi.org/10.1002/ppp3.5

Canavan K, Paterson ID, Lambertini C, Hill MP (2018b) Expansive reed populations-alien invasion or disturbed wetlands? AoB Plants 10:ply014

Chambers RM, Meyerson LA, Saltonstall K (1999) Expansion of Phragmites australis into tidal wetlands of North America. Aquat Bot 64:261-273

Chen J, Shafi M, Li S, Wang Y, Wu J, Ye Z, Peng D, Yan W, Liu D (2015) Copper induced oxidative stresses, antioxidant responses and phytoremediation potential of Moso bamboo (Phyllostachys pubescens). Sci Rep 5:13554

Coffman GC, Ambrose RF, Rundel PW (2010) Wildfire promotes dominance of invasive giant reed (Arundo donax) in riparian ecosystems. Biol Invasions 12:2723-2734

Colautti RI, Lau JA (2015) Contemporary evolution during invasion: evidence for differentiation, natural selection, and local adaptation. Mol Ecol 24:1999-2017

Colautti RI, Grigorovich IA, MacIsaac HJ (2006) Propagule pressure: a null model for biological invasions. Biol Invasions 8:1023-1037

Corneli E, Dragoni F, Adessi A, De Philippis R, Bonari E, Ragaglini G (2016) Energy conversion of biomass crops and agroindustrial residues by combined biohydrogen/ biomethane system and anaerobic digestion. Bioresour Technol 211:509-518

Cosentino SL, Copani V, D'Agosta GM, Sanzone E, Mantineo M (2006) First results on evaluation of Arundo donax L. clones collected in Southern Italy. Ind Crops Prod 23:212-222

Cousens R (2008) Risk assessment of potential biofuel species: an application for trait-based models for predicting weediness? Weed Sci 56:873-882

Czakó M, Feng X, He Y, Liang D, Márton L (2005) Genetic modification of wetland grasses for phytoremediation. Zeitschrift für Naturforschung 60c:285

Dansereau P (1951) Description and recording of vegetation upon a structural basis. Ecology 32:172-229
D'Antonio CM, Vitousek PM (1992) Biological invasions by exotic grasses, the grass/fire cycle, and global change. Annu Rev Ecol Syst 23:63-87

de Kroon H, Kalliola R (1995) Shoot dynamics of the giant grass Gynerium sagittatum in Peruvian Amazon floodplains, a clonal plant that does show self-thinning. Oecologia 101:124-131

Dehnen-Schmutz K, Touza J, Perrings C, Williamson M (2007) A century of the ornamental plant trade and its impact on invasion success. Divers Distrib 13:527-534

DeMalach N, Zaady E, Weiner J, Kadmon R (2016) Size asymmetry of resource competition and the structure of plant communities. J Ecol 104:899-910

Díaz S, Cabido M (1997) Plant functional types and ecosystem function in relation to global change. J Veg Sci 8:463-474

Domènech R, Vilà M, Gesti J, Serrasolses I (2006) Neighbourhood association of Cortaderia selloana invasion, soil properties and plant community structure in Mediterranean coastal grasslands. Acta Oecol 29:171-177

Dougherty RF (2013) Ecology and niche characterization of the invasive ornamental grass Miscanthus sinensis. Plant Pathology, Physiology, and Weed Science. Virginia Tech, Virginia Tech

Drewitz JJ, DiTomaso JM (2004) Seed biology of jubatagrass (Cortaderia jubata). Weed Sci 52:525-530

Dwire KA, Kauffman JB (2003) Fire and riparian ecosystems in landscapes of the western USA. For Ecol Manag 178:61-74

Ecker G, Zalapa J, Auer C (2015) Switchgrass (Panicum virgatum L.) genotypes differ between coastal sites and inland road corridors in the Northeastern US. PLoS ONE 10:e0130414

Edwards D (1983) A broad-scale structural classification of vegetation for practical purposes. Bothalia 14:705-712

Farrelly D (1984) The book of bamboo: a comprehensive guide to this remarkable plant, its uses, and its history. Thames and Hudson Ltd, London

Farrer EC, Goldberg DE (2009) Litter drives ecosystem and plant community changes in cattail invasion. Ecol Appl 19:398-412

Fischer T, Byerlee D, Edmeades G (2014) Crop yields and global food security: Will yield increase continue to feed the world? In: (ACIAR) TACfIAR (ed). Grains Research \& Development Corporation (GRDC), Canberra, pp xxii +634

Flory SL, Lorentz KA, Gordon DR, Sollenberger LE (2012) Experimental approaches for evaluating the invasion risk of biofuel crops. Environ Res Lett 7:045904

Fournier DA, Skaug HJ, Ancheta J, Ianelli J, Magnusson A, Maunder MN, Nielsen A, Sibert J (2012) AD Model Builder: using automatic differentiation for statistical inference of highly parameterized complex nonlinear models. Optim Methods Softw 27:233-249

Foxcroft LC, Richardson DM, Wilson JRU (2008) Ornamental plants as invasive aliens: problems and solutions in Kruger National Park, South Africa. Environ Manag 41:32-51

Gaertner M, Biggs R, Te Beest M, Hui C, Molofsky J, Richardson DM (2014) Invasive plants as drivers of regime shifts: identifying high-priority invaders that alter feedback relationships. Divers Distrib 20:733-744 
Gallagher RV, Randall RP, Leishman MR (2015) Trait differences between naturalized and invasive plant species independent of residence time and phylogeny. Conserv Biol 29:360-369

Garnier E, Navas M-L (2012) A trait-based approach to comparative functional plant ecology: concepts, methods and applications for agroecology. A review. Agron Sustain Dev 32:365-399

Garnier E, Stahl U, Laporte M-A, Kattge J, Mougenot I, Kühn I, Laporte B, Amiaud B, Ahrestani FS, Bönisch G, Bunker DE, Cornelissen JHC, Díaz S, Enquist BJ, Gachet S, Jaureguiberry $\mathrm{P}$, Kleyer M, Lavorel S, Maicher L, PérezHarguindeguy N, Poorter H, Schildhauer M, Shipley B, Violle C, Weiher E, Wirth C, Wright IJ, Klotz S (2017) Towards a thesaurus of plant characteristics: an ecological contribution. J Ecol 105:298-309

Gordon DR, Tancig KJ, Onderdonk DA, Gantz CA (2011) Assessing the invasive potential of biofuel species proposed for Florida and the United States using the Australian Weed Risk Assessment. Biomass Bioenergy 35:74-79

Gordon-Gray KD, Ward CJ (1971) A contribution to knowledge of Phragmites (Gramineae) in South Africa, with particular reference to Natal populations. S Afr J Sci 37:1-30

Grace JB (1993) The adaptive significance of clonal reproduction in angiosperms: an aquatic perspective. Aquat Bot 44:159-180

Grime JP, Hodgson JG, Hunt RJ (1988) Comparative plant ecology. A functional approach to common British species. Unwyn Hyman, London

Hardion L, Verlaque R, Baumel A, Juin M, Vila B (2012) Revised systematics of Mediterranean Arundo (Poaceae) based on AFLP fingerprints and morphology. Taxon 61:1217-1226

Hartman JC, Nippert JB, Orozco RA, Springer CJ (2011) Potential ecological impacts of switchgrass (Panicum virgatum L.) biofuel cultivation in the Central Great Plains, USA. Biomass Bioenergy 35:3415-3421

Haslam SM (2010) A book of reed: (Phragmites australis (Cav.) Trin. ex Steudel, formerly Phragmites communis Trin, Forrest Text, Tresaith, UK

Heaton EA, Dohleman FG, Long SP (2008) Meeting US biofuel goals with less land: the potential of Miscanthus. Glob Change Biol 14:2000-2014

Herrera AM, Dudley TL (2003) Reduction of riparian arthropod abundance and diversity as a consequence of giant reed (Arundo donax) invasion. Biol Invasions 5:167-177

Holdredge C, Bertness MD (2011) Litter legacy increases the competitive advantage of invasive Phragmites australis in New England wetlands. Biol Invasions 13:423-433

Holmes PM, Richardson DM, Esler KJ, Witkowski ETF, Fourie S (2005) A decision-making framework for restoring riparian zones degraded by invasive alien plants in South Africa: review article. S Afr J Sci 101:553-564

Isagi Y, Oda T, Fukushima K, Lian C, Yokogawa M, Kaneko S (2016) Predominance of a single clone of the most widely distributed bamboo species Phyllostachys edulis in East Asia. J Plant Res 129:21-27

IUCN (2009) Guidance on biofuels and Invasive species. IUCN, Gland
Jaiswal RK, Mukherjee S, Raju KD, Saxena R (2002) Forest fire risk zone mapping from satellite imagery and GIS. Int $\mathbf{J}$ Appl Earth Obs Geoinf 4:1-10

Jakob K, Zhou F (2009) Genetic improvement of C4 grasses as cellulosic biofuel feedstocks. In Vitro Cell Dev Biol Plant 45:291-305

Jung SJ, Kim SH, Chung IM (2015) Comparison of lignin, cellulose, and hemicellulose contents for biofuels utilization among 4 types of lignocellulosic crops. Biomass Bioenergy 83:322-327

Kettenring KM, McCormick MK, Baron HM, Whigham DF (2011) Mechanisms of Phragmites australis invasion: feedbacks among genetic diversity, nutrients, and sexual reproduction. J Appl Ecol 48:1305-1313

Küchler AW (1949) A physiognomic classification of vegetation. Ann Assoc Am Geogr 39:201-210

Kueffer C, Pyšek P, Richardson DM (2013) Integrative invasion science: model systems, multi-site studies, focused metaanalysis and invasion syndromes. New Phytol 200:615-633

Lambert AM, Dudley TL, Saltonstall K (2010) Ecology and impacts of the large-statured invasive grasses Arundo donax and Phragmites australis in North America. Invasive Plant Sci Manag 3:489-494

Lambrinos JG (2000) The impact of the invasive alien grass Cortaderia jubata (Lemoine) Stapf on an endangered mediterranean type shrubland in California. Divers Distrib 6:217-231

Larpkern P, Moe SR, Totland Ø (2011) Bamboo dominance reduces tree regeneration in a disturbed tropical forest. Oecologia 165:161-168

Lavergne S, Molofsky J (2007) Increased genetic variation and evolutionary potential drive the success of an invasive grass. Proc Natl Acad Sci 104:3883-3888

Lavorel S, McIntyre S, Landsberg J, Forbes TDA (1997) Plant functional classifications: from general groups to specific groups based on response to disturbance. Trends Ecol Evol 12:474-478

Liese W, Köhl M (2015) Bamboo: the plant and its uses. Springer, Berlin

Lieurance D, Cooper A, Young AL, Gordon DR, Flory SL (2018) Running bamboo species pose a greater invasion risk than clumping bamboo species in the continental United States. J Nat Conserv 43:39-45

Lima RAF, Rother DC, Muler AE, Lepsch IF, Rodrigues RR (2012) Bamboo overabundance alters forest structure and dynamics in the Atlantic Forest hotspot. Biol Conserv 147:32-39

Linder HP, Lehmann CER, Archibald S, Osborne CP, Richardson DM (2018) Global grass (Poaceae) success underpinned by traits facilitating colonization, persistence and habitat transformation. Biol Rev Camb Philos Soc 93:1125-1144

Lishawa SC, Lawrence BA, Albert DA, Tuchman NC (2015) Biomass harvest of invasive Typha promotes plant diversity in a Great Lakes coastal wetland. Restor Ecol 23:228-237

Maceda-Veiga A, Basas H, Lanzaco G, Sala M, de Sostoa A, Serra A (2016) Impacts of the invader giant reed (Arundo donax) on riparian habitats and ground arthropod communities. Biol Invasions 18:731-749 
McCormick MK, Kettenring KM, Baron HM, Whigham DF (2010) Spread of invasive Phragmites australis in estuaries with differing degrees of development: genetic patterns, Allee effects and interpretation. J Ecol 98:1369-1378

McWilliams JD (2004) Arundo donax. Fire effects information system U.S. Department of Agriculture. Forest Service, Rocky Mountain Research Station, Fire Sciences Laboratory, Missoula

Meffin R (2013) Alien Brassica: variation in performance among and within species and locations. Lincoln University, Lincoln

Meyerson LA (2000) Ecosystem-level effects of invasive species: a Phragmites case study in two freshwater tidal marsh ecosystems on the Connecticut River. School of Forestry and Environmental Studies, Yale University

Meyerson LA (2013) Evidence for multiple introductions of Phragmites australis to North America: detection of a new non-native haplotype. Biol Invasions 15:2605-2608

Meyerson LA, Chambers RM, Vogt KA (1999) The effects of Phragmites removal on nutrient pools in a freshwater tidal marsh ecosystem. Biol Invasions 1:129-136

Meyerson LA, Saltonstall K, Windham L, Kiviat E, Findlay S (2000) A comparison of Phragmites australis in freshwater and brackish marsh environments in North America. Wetl Ecol Manag 8:89-103

Meyerson LA, Viola DV, Brown RN (2010) Hybridization of invasive Phragmites australis with a native subspecies in North America. Biol Invasions 12:103-111

Mirza N, Mahmood Q, Pervez A, Ahmad R, Farooq R, Shah MM, Azim MR (2010) Phytoremediation potential of Arundo donax in arsenic-contaminated synthetic wastewater. Bioresour Technol 101:5815-5819

Mislevy P, Fluck RC (1992) Harvesting operations and energetics of tall grasses for biomass energy production: a case study. Biomass Bioenergy 3:381-387

Montti L, Villagra M, Campanello PI, Gatti MG, Goldstein G (2014) Functional traits enhance invasiveness of bamboos over co-occurring tree saplings in the semideciduous Atlantic Forest. Acta Oecol Int J Ecol 54:36-44

Moodley D, Geerts S, Richardson DM, Wilson JRU (2013) Different traits determine introduction, naturalization and invasion success in woody plants: proteaceae as a test case. PLoS ONE 8:e75078

Novoa A, Le Roux JJ, Robertson MP, Wilson JRU, Richardson DM (2015) Introduced and invasive cactus species: a global review. AoB Plants 7:plu078

O'Connor PJ, Covich AP, Scatena FN, Loope LL (2000) Nonindigenous bamboo along headwater streams of the Luquillo Mountains, Puerto Rico: leaf fall, aquatic leaf decay and patterns of invasion. J Trop Ecol 16:499-516

Okada M, Ahmad R, Jasieniuk M (2007) Microsatellite variation points to local landscape plantings as sources of invasive pampas grass (Cortaderia selloana) in California. Mol Ecol 16:4956-4971

Onimaru K, Yabe K (1996) Comparisons of nutrient recovery and specific leaf area variation between Carex lasiocarpa var. occultans and Carex thunbergii var. appendiculata with reference to nutrient conditions and shading by Phragmites australis. Ecol Res 11:139-147

Packer JG, Meyerson LA, Richardson DM, Brundu G, Allen WJ, Bhattarai GP, Brix H, Canavan S, Castiglione S,
Cicatelli A, Čuda J, Cronin JT, Eller F, Guarino F, Guo W-H, Guo X, Hierro JL, Lambertini C, Liu J, Lozano V, Mozdzer TJ, Skálová H, Villarreal D, Wang R-Q, Pyšek P (2017) Global networks for invasion science: benefits, challenges and guidelines. Biol Invasions 19:1081-1096

Pagad S (2016) Bamboos and invasiveness- identifying which bamboo species pose a risk to the natural environment and what can be done to reduce this risk. INBAR Working Paper No.77. International Network for Bamboo and Rattan, Beijing, China

Pérez-Harguindeguy N, Díaz S, Garnier E, Lavorel S, Poorter H, Jaureguiberry P, Bret-Harte MS, Cornwell WK, Craine JM, Gurvich DE, Urcelay C, Veneklaas EJ, Reich PB, Poorter L, Wright IJ, Ray P, Enrico L, Pausas JG, de Vos AC, Buchmann N, Funes G, Quétier F, Hodgson JG, Thompson K, Morgan HD, ter Steege H, Sack L, Blonder B, Poschlod P, Vaieretti MV, Conti G, Staver AC, Aquino S, Cornelissen JHC (2016) Corrigendum to: new handbook for standardised measurement of plant functional traits worldwide. Aust J Bot 64:715-716

Pokorny ML, Sheley RL, Zabinski CA, Engel RE, Svejcar TJ, Borkowski JJ (2005) Plant functional group diversity as a mechanism for invasion resistance. Restor Ecol 13:448-459

Pyšek P, Richardson DM (2008) Traits associated with invasiveness in alien plants: Where do we stand? In: Nentwig W (ed) Biological invasions. Ecological studies (analysis and synthesis). Springer, Berlin, pp 97-125

Pyšek P, Jarošík V, Hulme PE, Kühn I, Wild J, Arianoutsou M, Bacher S, Chiron F, Didžiulis V, Essl F, Genovesi P, Gherardi F, Hejda M, Kark S, Lambdon PW, DesprezLoustau M-L, Nentwig W, Pergl J, Poboljšaj K, Rabitsch W, Roques A, Roy DB, Shirley S, Solarz W, Vilà M, Winter M (2010) Disentangling the role of environmental and human pressures on biological invasions across Europe. Proc Natl Acad Sci 107:12157-12162

Pyšek P, Jarošík V, Hulme PE, Pergl J, Hejda M, Schaffner U, Vilà M (2012) A global assessment of invasive plant impacts on resident species, communities and ecosystems: the interaction of impact measures, invading species' traits and environment. Glob Change Biol 18:1725-1737

Pyšek P, Skálová H, Čuda J, Guo W-Y, Suda J, Doležal J, Kauzál O, Lambertini C, Lučanová M, Mandáková T, Moravcová L, Pyšková K, Brix H, Meyerson LA (2018) Small genome separates native and invasive populations in an ecologically important cosmopolitan grass. Ecology 99:79-90

Quinn LD, Allen DJ, Stewart JR (2010) Invasiveness potential of Miscanthus sinensis: implications for bioenergy production in the United States. GCB Bioenergy 2:310-320

Razanajatovo M, Maurel N, Dawson W, Essl F, Kreft H, Pergl J, Pyšek P, Weigelt P, Winter M, van Kleunen M (2016) Plants capable of selfing are more likely to become naturalized. Nat Commun 7:13313

Richardson DM, Blanchard R (2011) Learning from our mistakes: minimizing problems with invasive biofuel plants. Curr Opin Environ Sustain 3:36-42

Richardson DM, Holmes PM, Esler KJ, Galatowitsch SM, Stromberg JC, Kirkman SP, Pyšek P, Hobbs RJ (2007a) Riparian vegetation: degradation, alien plant invasions, and restoration prospects. Divers Distrib 13:126-139 
Richardson DM, Rundel PW, Jackson ST, Teskey RO, Aronson J, Bytnerowicz A, Wingfield MJ, Proches S (2007b) Human impacts in pine forests: past, present, and future. Annu Rev Ecol Evol Syst 38:275-297

Rieger JP, Kreager DA (1989) Giant reed (Arundo donax): a climax community of the riparian zone. Protection, management, and restoration for the 1990's. In: Proceedings of the California riparian systems conference. US Department of Agriculture, Forest Service, Pacific Southwest Forest and Range Experiment Station, Berkeley, California, pp 222-225

Rohani S, Dullo B, Woudwijk W, de Hoop P, Kooijman A, Grootjans AP (2014) Accumulation rates of soil organic matter in wet dune slacks on the Dutch Wadden Sea islands. Plant Soil 380:181-191

Rossiter NA, Setterfield SA, Douglas M, Hutley LB (2003) Testing the grass-fire cycle: alien grass invasion in the tropical savannas of northern Australia. Divers Distrib 9:169-176

Rossiter-Rachor NA, Setterfield SA, Douglas MM, Hutley LB, Cook GD, Schmidt S (2009) Invasive (gamba grass) is an ecosystem transformer of nitrogen relations in Australian savanna. Ecol Appl 19(6):1546-1560

Rother DC, Rodrigues RR, Pizo MA (2016) Bamboo thickets alter the demographic structure of Euterpe edulis population: a keystone, threatened palm species of the Atlantic forest. Acta Oecol 70:96-102

Saltonstall K (2002) Cryptic invasion by a non-native genotype of the common reed, Phragmites australis, into North America. Proc Natl Acad Sci USA 99:2445-2449

Saltonstall K, Lambert A, Meyerson LA (2010) Genetics and reproduction of common (Phragmites australis) and giant reed (Arundo donax). Invasive Plant Sci Manag 3:495-505

Schnitzler A, Essl F (2015) From horticulture and biofuel to invasion: the spread of Miscanthus taxa in the USA and Europe. Weed Res 55:221-225

Scurlock JMO, Dayton DC, Hames B (2000) Bamboo: an overlooked biomass resource? Biomass Bioenergy 19:229-244

SFAPRC (2006) Statistics of forest resources in China (1999-2003). State Forestry Administration, China. http:// www.forestry.gov.cn/portal/main/s/65/content-90.html (In Chinese)

Sheley RL, James J (2010) Resistance of native plant functional groups to invasion by medusahead (Taeniatherum caputmedusae). Invasive Plant Sci Manag 3:294-300

Singh AN, Singh JS (1999) Biomass, net primary production and impact of bamboo plantation on soil redevelopment in a dry tropical region. For Ecol Manag 119:195-207

Smith MD, van Wilgen BW, Burns CE, Govender N, Potgieter ALF, Andelman S, Biggs HC, Botha J, Trollope WSW (2013) Long-term effects of fire frequency and season on herbaceous vegetation in savannas of the Kruger National Park, South Africa. J Plant Ecol 6:71-83

Smith LL, Tekiela DR, Barney JN (2015) Predicting biofuel invasiveness: a relative comparison to crops and weeds. Invasive Plant Sci Manag 8:323-333

Soderstrom TR, Calderon CE (1979) A commentary on the bamboos (Poaceae: Bambusoideae). Biotropica 11:161-172
Soltis PS, Soltis DE (2000) The role of genetic and genomic attributes in the success of polyploids. Proc Natl Acad Sci USA 97:7051-7057

Song Q-n LuH, Liu J, Yang J, G-y Yang, Q-p Yang (2017) Accessing the impacts of bamboo expansion on NPP and N cycling in evergreen broadleaved forest in subtropical China. Sci Rep 7:40383

Soreng RJ, Peterson PM, Romaschenko K, Davidse G, Zuloaga FO, Judziewicz EJ, Filgueiras TS, Davis JI, Morrone O (2015) A worldwide phylogenetic classification of the Poaceae (Gramineae). J Syst Evol 53(2):117-137

Stueffer JF, De Kroon H, During HJ (1996) Exploitation of environmental hetergeneity by spatial division of labor in a clonal plant. Funct Ecol 10:328-334

Suzaki T, Nakatsubo T (2001) Impact of the bamboo Phyllostachys bambusoides on the light environment and plant communities on riverbanks. J For Res 6:81-86

Tang Y, Washitani I, Tsuchiya T, Iwaki H (1990) Growth analysis of Quercus serrata seedlings within Miscanthus sinensis grass canopies differing in light availability. Ecol Res 5:367-376

Teixeira JS, Oatham MP (2001) An investigation into the effect of bamboo on the surrounding vegetation in the arena forest reserve. The living world. J Trinidad Tobago Field Nat Club 13-20

Thompson K, Hodgson JG, Tim CGR (1995) Native and alien invasive plants: more of the same? Ecography 18:390-402

Thomson FJ, Moles AT, Auld TD, Kingsford RT (2011) Seed dispersal distance is more strongly correlated with plant height than with seed mass. J Ecol 99:1299-1307

Tilman D (1982) Resource competition and community structure. Princeton University Press, Princeton

Tilman D, Knops J, Wedin D, Reich P, Ritchie M, Siemann E (1997) The influence of functional diversity and composition on ecosystem processes. Science 277:1300-1302

Van Doninck K, Schon I, De Bruyn L, Martens K (2002) A general purpose genotype in an ancient asexual. Oecologia 132:205-212

van Kleunen M, Stuefer JF (1999) Quantifying the effects of reciprocal assimilate and water translocation in a clonal plant by the use of steam-girdling. Oikos 85:135-145

van Kleunen M, Johnson SD, Fischer M (2007) Predicting naturalization of southern African Iridaceae in other regions. J Appl Ecol 44:594-603

van Kleunen M, Dawson W, Essl F, Pergl J, Winter M, Weber E, Kreft H, Weigelt P, Kartesz J, Nishino M, Antonova LA, Barcelona JF, Cabezas FJ, Cardenas D, Cardenas-Toro J, Castano N, Chacon E, Chatelain C, Ebel AL, Figueiredo E, Fuentes N, Groom QJ, Henderson L, Inderjit Kupriyanov A, Masciadri S, Meerman J, Morozova O, Moser D, Nickrent DL, Patzelt A, Pelser PB, Baptiste MP, Poopath M, Schulze M, Seebens H, Shu WS, Thomas J, Velayos M, Wieringa JJ, Pysek P (2015) Global exchange and accumulation of non-native plants. Nature 525:100-103

van Kleunen M, Essl F, Perg J, Brundu G, Carboni M, Dullinger S, Early R, González-Moreno P, Groom QJ, Hulme PE, Kueffer C, Kühn I, Máguas C, Maurel N, Novoa A, Parepa M, Pyšek P, Seebens H, Tanner R, Touza J, Verbrugge L, Weber E, Dawson W, Kreft H, Weigelt P, Winter M, Klonner G, Talluto MV, Dehnen-Schmutz K (2018) The 
changing role of ornamental horticulture in alien plant invasions. Biol Rev 93(3):1421-1437

Vilà M, Pujadas J (2001) Land-use and socio-economic correlates of plant invasions in European and North African countries. Biol Conserv 100:397-401

Visser V, Wilson JRU, Fish L, Brown C, Cook GD, Richardson DM (2016) Much more give than take: South Africa as a major donor but infrequent recipient of invasive non-native grasses. Global Ecol Biogeogr 25:679-692

Vorontsova MS, Clark LG, Dransfield J, Govaerts R, Baker WJ (2016) World checklist of bamboos and rattans. INBAR Technical Report No. 37. International Network of Bamboo \& Rattan, Beijing, China

Wang J, Ge Y, Zhang CB, Bai Y, Du ZK (2013) Dominant functional group effects on the invasion resistance at different resource levels. PLoS ONE 8:e77220

Wang Y, Bai S, Binkley D, Zhou G, Fang F (2016) The independence of clonal shoot's growth from light availability supports moso bamboo invasion of closed-canopy forest. For Ecol Manag 368:105-110
Wang Y-J, Müller-Schärer H, van Kleunen M, Cai A-M, Zhang P, Yan R, Dong B-C, Yu F-H (2017) Invasive alien plants benefit more from clonal integration in heterogeneous environments than natives. New Phytol 216:1072-1078

Welker JM, Briske DD (1992) Clonal biology of the temperate, caespitose, Graminoid Schizachyrium scoparium: a synthesis with reference to climate change. Oikos 63:357-365

Westoby M, Falster DS, Moles AT, Vesk PA, Wright IJ (2002) Plant ecological strategies: some leading dimensions of variation between species. Annu Rev Ecol Syst 33:125-159

Xu Q-F, Jiang P-K, Wu J-S, Zhou G-M, Shen R-F, Fuhrmann JJ (2014) Bamboo invasion of native broadleaf forest modified soil microbial communities and diversity. Biol Invasions 17:433-444

Young SL, Barney JN, Kyser GB, Jones TS, DiTomaso JM (2009) Functionally similar species confer greater resistance to invasion: implications for grassland restoration. Restor Ecol 17:884-892 